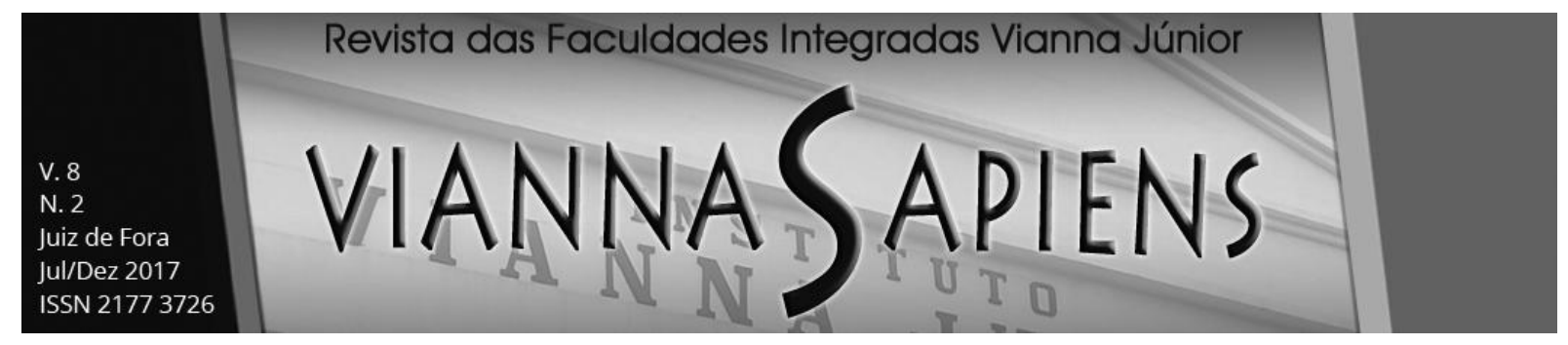

\title{
JUDICIALIZAÇÃO DO DIREITO À SAÚDE E COMPORTAMENTO JURISPRUDENCIAL DO SUPREMO TRIBUNAL FEDERAL
}

\author{
Thanderson Pereira de Sousa ${ }^{1}$ \\ Juliana Jacob ${ }^{2}$ \\ Bruno Marques Albuquerque ${ }^{3}$
}

\section{RESUMO}

A saúde ficou reconhecida na Constituição de 1988 como direito social, devendo ser implementada por intermédio de políticas sociais e econômicas. Nesse contexto o presente artigo aborda a judicialização da saúde no Brasil pós 88. Pretende-se analisar a possibilidade de o Judiciário efetivar o direito à saúde através da concretização de políticas públicas, identificando o entendimento que resta clarificado na jurisprudência do STF e o que isto revela no contexto brasileiro. A abordagem metodológica dos escritos é essencialmente qualitativa, apoiada em técnicas de pesquisa bibliográfica e documental. Do estudo realizado infere-se que o Poder Judiciário poderá concretizar o direito a saúde frente a omissão dos Poderes políticos responsáveis primariamente, restaurando a autoridade constitucional. A jurisprudência do Supremo é pacífica nesta orientação, podendo ser caracterizada por uma ação minimalis-

\footnotetext{
${ }^{1}$ Mestrando pelo Programa de Pós-Graduação em Direito da Universidade Federal do Ceará (UFC); Especialista em Direito Eleitoral pela Universidade Cândido Mendes (UCAM); Bacharel em Direito pelo Instituto Camilo Filho (ICF). e-mail: thandersonsousa@hotmail.com

2 Mestre em Ciências Jurídico-Políticas pela Universidade de Lisboa (ULISBOA); Especialista em Ciências Penais pela Universidade Federal de Juiz de Fora (UFJF); Bacharelada em Direito pela Faculdades Integradas Vianna Junior, email: jujacob0206@gmail.com

${ }^{3}$ Mestrando em Planejamento e Políticas Públicas pela Universidade Estadual do Ceará (UECE); Bacharel em Direito pela Universidade de Fortaleza (UNIFOR); Especialista em Direito e Processo Eleitoral pela Escola Superior da Magistratura do Estado do Ceará (ESMEC); Pós-Graduado em Serviço Social, Políticas Públicas e Direitos Sociais pela Universidade Estadual do Ceará (UECE); Membro do Instituto Latino-Americano de Estudos sobre Direito, Política e Democracia (ILAEDPD), email: brumaral@hotmail.com
} 


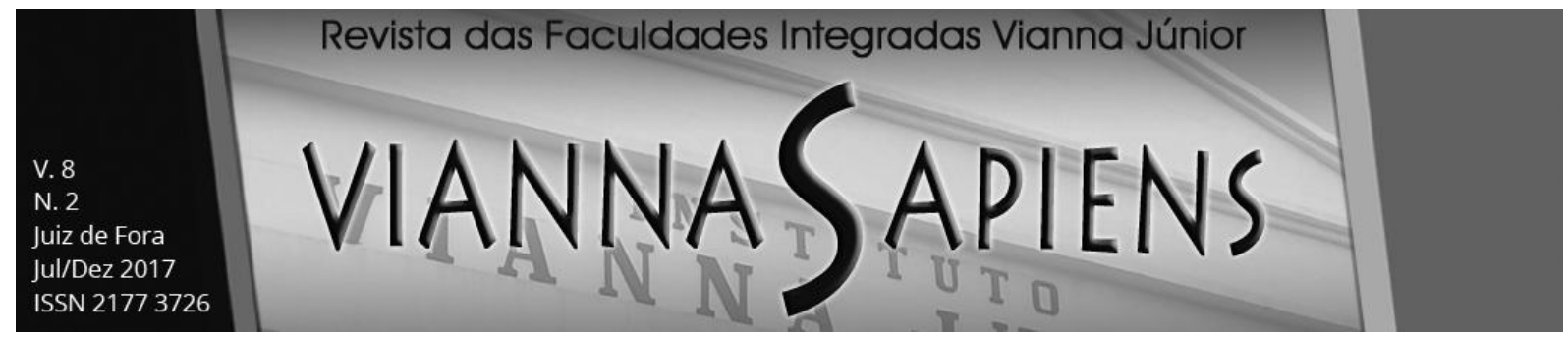

ta. Por último consigna-se que a tendência é que o Judiciário se torne ainda mais ativo dado a nova política fiscal do Estado.

\section{PALAVRAS-CHAVE: DIREITOS FUNDAMENTAIS. POLÍTICAS PÚBLICAS. JUDI- CIALIZAÇÃO.}

\section{INTRODUÇÃO}

A seara do direito à saúde - e Políticas Públicas decorrentes deste direito - é solo copioso para discussão no âmbito do Poder Judiciário. Cresce cada vez mais no Brasil o número de ações versando sobre o Direito Fundamental à saúde - previsto nos artigos 6º, 196 e seguintes da Constituição Federal de 1988 (CF/88).

Consequentemente, emerge-se grande debate em torno da possibilidade de o Judiciário implementar Políticas Públicas de saúde. Nesse esteio, o presente artigo visa tematicamente abordar a concretização do direito à saúde pelo Poder Judiciário - de forma particular pelo Supremo Tribunal Federal (STF) - e seu comportamento jurisprudencial.

A problemática que impulsiona este estudo gira em torno das seguintes indagações: o Poder Judiciário tem competência para concretizar o Direito Fundamental à saúde? A atuação voluntariosa do Judiciário, nestes casos específicos, viola o princípio da separação dos Poderes? O que a jurisprudência do STF pacífica e revela? Qual a repercussão da emenda constitucional n. ${ }^{\circ} 95$ ?

A justificativa para estes escritos se assenta na necessidade de compreender os rumos e a importância da atividade judicial num contexto de crise, marcado pela ineficiência dos serviços públicos, corrupção, corte de gastos com a persecução de Direitos Fundamentais Sociais, dentre outros fatores. É relevante identificar as possíveis contribuições ou prejuízos que as atuações dos Tribunais podem provocar dentro do Estado Social de Direito. 


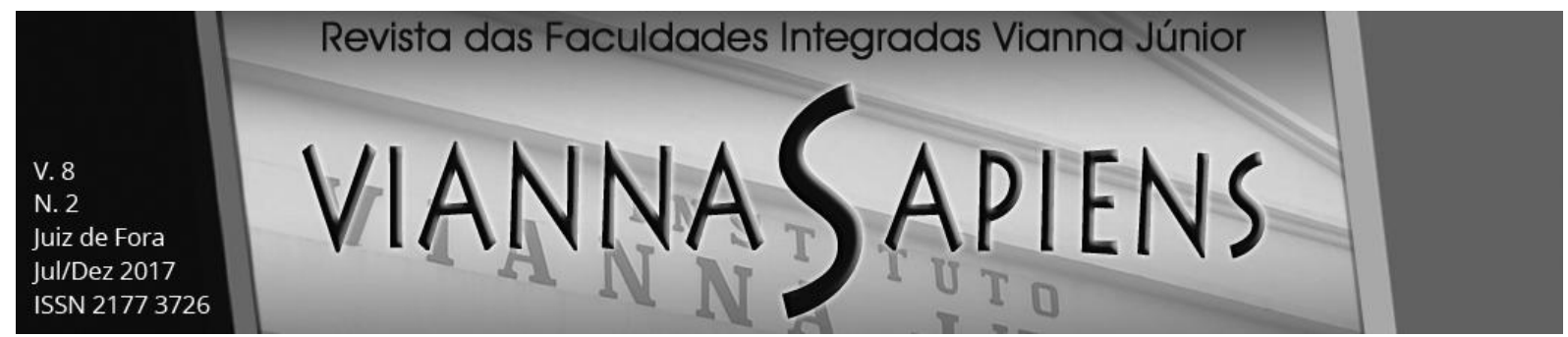

Constitui objetivo primordial analisar a possibilidade de o Judiciário efetivar 0 direito à saúde através da concretização de Políticas Públicas de saúde, identificando o entendimento que resta clarificado na jurisprudência do STF e o que isto revela no contexto brasileiro.

A abordagem metodológica é essencialmente qualitativa, almejando por intermédio de investigação científica descrever e explorar as particularidades do fenômeno da judicialização do direito à saúde e suas implicações. Conta com técnicas de pesquisa bibliográfica, realizando a dita investigação com base em estudos de referência na temática abordada, e pesquisa documental, analisando e interpretando à luz da doutrina utilizada documentos jurídicos - Arguição de Descumprimento de Preceito Fundamental (ADPF) n. ${ }^{\circ} 45$, e, o Agravo Regimental (AgR) em Suspensão de Tutela Antecipada n. ${ }^{0} 175$ - além de pesquisas empíricas realizadas pelo Instituto Datafolha.

Depreende-se desta investigação científica que o Poder Judiciário pode efetivar o Direito Fundamental à saúde por intermédio da concretização de Políticas Públicas - fenômeno da desneutralização política - desde que esteja apurada a omissão e negligência do Poder Político responsável por delinear materialmente os preceitos constitucionais (situação que tende a se agravar com a limitação dos gastos públicos), não violando, portanto, o princípio da separação dos Poderes.

A jurisprudência do Supremo Tribunal Federal (STF), demonstra que as decisões tomadas, seja em sede de controle de constitucionalidade concentrado ou difuso, não dizem respeito "ao que decidir", mas sobre "como decidir", dando ao comportamento jurisprudencial dessa corte um caráter minimalista. Nota-se ainda grande desconfiança no Poder Executivo e nos serviços públicos de saúde.

Assim, o artigo está estruturado em dois tópicos. O primeiro dissertando sobre a possibilidade de atuação do Poder Judiciário e as peculiaridades que envolvem essa atuação, e, o segundo alcançando a jurisprudência do Supremo Tribunal Federal (STF), revelando o que ela consolida e revela. 


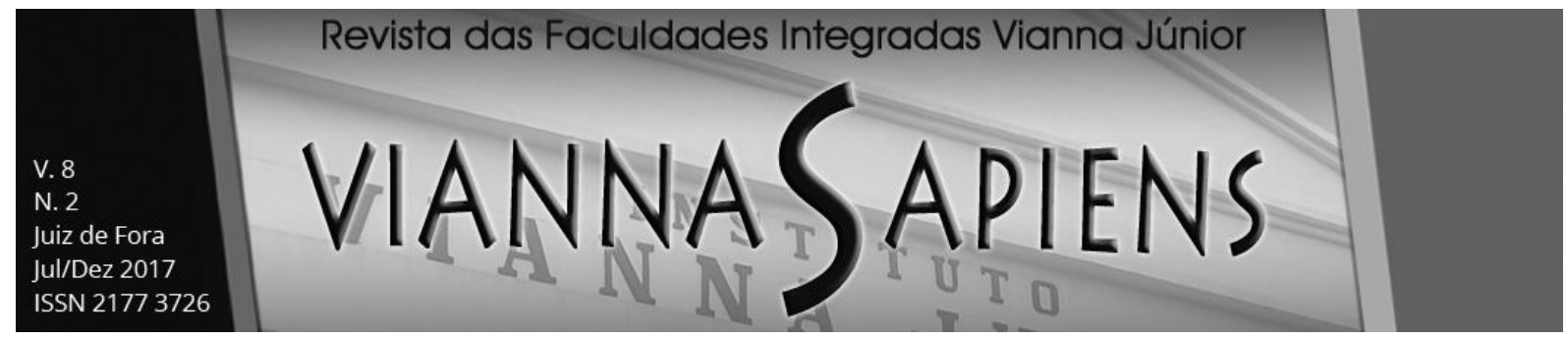

\section{A POSSIBILIDADE DO SUPREMO TRIBUNAL FEDERAL CONFORMAR POLÍ- TICAS PÚBLICAS DE SAÚDE}

O direito à saúde passou a ser tido - com a Constituição Federal de 1988 (CF/88) - como Direito Fundamental Social, estando previsto no Art. 6e e também entre os Arts. 196 e 200. De acordo com o texto constitucional é dever do Estado garantir, com a adoção de Políticas Sociais e Econômicas, a saúde de todos buscando a redução de doenças e outros agravos, assim como oferecer ações e serviços para a sua promoção, proteção e recuperação, em caráter universal e igualitário.

Sendo assim, Araújo (2009) pontua que o direito à saúde percorreu um longo caminho até sua devida incorporação na ordem constitucional brasileira vigente. $A$ saúde teve um caráter extremamente corporativista, sendo os serviços de saúde prestados somente para os trabalhadores formais e também aqueles indivíduos com capacidade econômica suficiente para o custeio dos serviços e produtos do segmento.

Infelizmente, mesmo com a introdução da saúde no rol dos Direitos Fundamentais pela $\mathrm{CF} / 88$, percebe-se que existem problemas no momento da consolidação deste direito, já que ações e serviços prestados pelo Sistema Único de Saúde (SUS), padecem de grave ineficiência. Com base em pesquisa realizada pelo Instituto Datafolha em novembro de 2016, grande parte dos brasileiros considera a saúde como o principal problema do país, estando a frente até mesmo da corrupção e do desemprego.

No caso, para $37 \%$ dos entrevistados, a saúde é o primeiro problema mais gritante do país, seguido pela corrupção com $18 \%$ da opinião, e, o desemprego, por sua vez com $15 \%$ da apreciação captada pela pesquisa. Na mesma linha, $82 \%$ dos brasileiros que participaram das entrevistas, utilizaram o SUS e seus respectivos serviços nos dois anos anteriores, e, destes, $65 \%$ classificou a qualidade prestacional como "péssima" (DATAFOLHA, 2016).

A pesquisa revelou ainda que a percepção da "péssima" qualidade dos serviços de saúde e do SUS, é equivalente entre os usuários e não usuários, no qual 


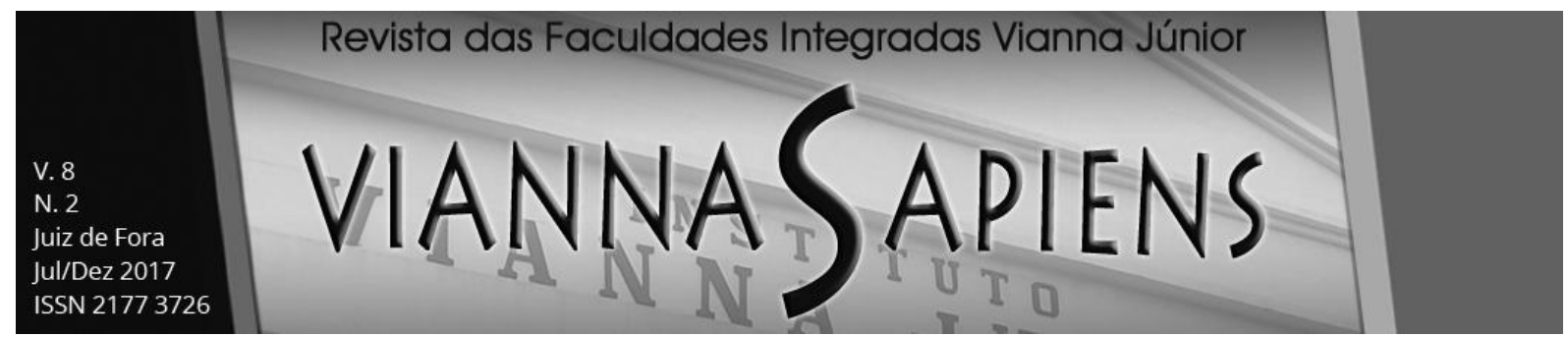

$51 \%$ opinaram nesta orientação. A coleta de dados abriu espaço ainda para breve manifestação dos participantes em referência as ações que devem ser tomadas para o melhoramento do SUS, sendo as principais medidas indicadas a diminuição da corrupção, o aumento do quantitativo de profissionais de saúde e aumento de leitos oferecidos (DATAFOLHA, 2016).

Infere-se, portanto, da referida pesquisa que a população brasileira está insatisfeita com a qualidade dos serviços de saúde prestados pelo sistema público através do SUS - a maior Política Pública de saúde do Brasil. O direito à saúde tem enfrentado vários óbices no caminho para a sua consolidação. A saúde perfaz Direito Fundamental, tanto do aspecto material quanto formal, vinculando a atuação dos Poderes Executivo e Legislativo (CARDOSO, 2017), assim os problemas do SUS prejudicam a consubstancialização de um imperativo constitucional chamado saúde.

Como consequência, os administrados diante dessa grave violação a Direito Fundamental, recorrem ao Poder Judiciário para fazer valer suas necessidades garantidas e positivadas na ordem constitucional. Dessa forma, observadas a mora do legislador (que se omite em criar Políticas Públicas eficientes, e a negligência do Poder Executivo em concretizar, velando pela eficiência do SUS - o direito à saúde no Brasil), a sociedade tem recorrido reiteradamente à tutela jurisdicional na busca da efetividade da saúde e o Supremo Tribunal Federal (STF) - enquanto guardião da Constituição - finda decidindo sobre esta temática. ${ }^{4}$

Como observa Sarlet (2006), o direito à saúde tem sua normatização constitucional mais complexa nos Arts. 196 e seguintes, mas assim como outros direitos prestacionais lhe é negada a natureza de norma de eficácia plena, sendo necessária a intervenção do Poder Judiciário para o alcance de eficácia. Desse modo levando em consideração a delineação constitucional do direito à saúde e a realidade brasileira, a seara das Políticas Públicas na área da saúde é solo copioso para discussões judiciais (SANTANA, 2009) e assim é porque as normas constitucionais se qua-

\footnotetext{
${ }^{4}$ Nessa orientação o RE no 684612 RG/RS (Min. Relatora Carmem Lúcia, 06/02/2014) e o Al - AgRg no 810864 (Min. Relator Luis Roberto Barroso, 18/11/2014), bem como diversas decisões semelhantes a saber: RE no $271286 \mathrm{AgRg} / \mathrm{RS}$ e RE no $716.777 \mathrm{AgRg} / \mathrm{RS}$.
} 


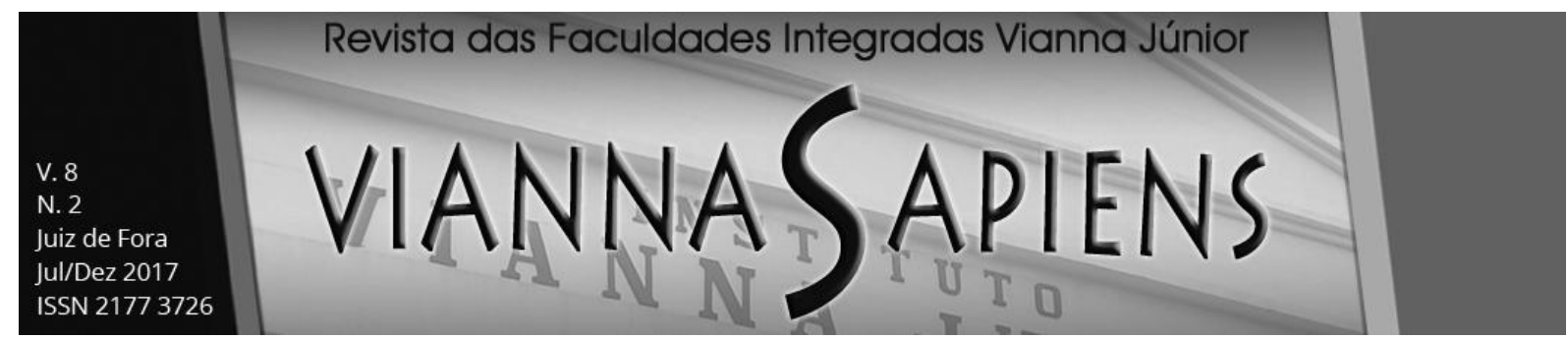

lificam pelo critério da efetividade, deixando de serem "percebidas como um documento estritamente político, mera convocação à atuação do Legislativo e do Executivo, [passando] a desfrutar de aplicabilidade direta e imediata, por juízes e tribunais" (BARROSO, p. 13, 2009, grifo do autor).

As demandas judiciais foram tantas que, segundo Wang (2015), em 2009 o STF realizou audiência pública em saúde reunindo especialistas da área, autoridades públicas, advogados e organizações civis com a finalidade de discutirem a judicialização desse direito e obterem técnicas científicas, administrativas, políticas e econômicas para que o Tribunal pudesse orientar e uniformizar suas decisões.

Para Ventura et al ( 2010, p. 01), "o fenômeno envolve aspectos políticos, sociais, éticos e sanitários, que vão muito além de seu componente jurídico e de gestão de serviços públicos", os laços entre direito, política e saúde pública intensificaram-se muito, a intervenção judiciária, e consequentemente a jurisprudência, refletem isto. Logo, é necessário identificar o Poder Judiciário - enquanto instituição do Estado Democrático de Direito, capaz de intervir na vida dos cidadãos, podendo concretizar direitos e promover a emancipação social.

Assim, ocorre uma troca dos responsáveis pelo cumprimento das funções estatais (quando o Judiciário determina o cumprimento de Política Pública de saúde) e Perez (2012) explica que esse fenômeno pode ser entendido inclusive a partir da própria Constituição. $\mathrm{O}$ autor cita dois exemplos claros, que é o caso das medidas provisórias, em que "retirou-se do Poder Legislativo [...] a investidura na função legislativa primária, para conferi-la ao Executivo" (ROTHENBURG, 2005, p. 33) e o mandado de injunção, caso em que o STF passa a deter competência para regular situação concreta perante a inexistência de regulamentação geral pelo legislador ou administrador.

Esta troca de responsáveis ou "Desneutralização Política do Judiciário", de acordo como Cambi (2009) prefere chamar, gera uma discussão acirrada e isso se deve ao fato de uma grande parte das discussões tratarem esse fenômeno - a judicialização e consequentemente a desneutralização - como algo essencialmente negativo sem dispensar um estudo mais estruturado em relação ao tema, muitas vezes 


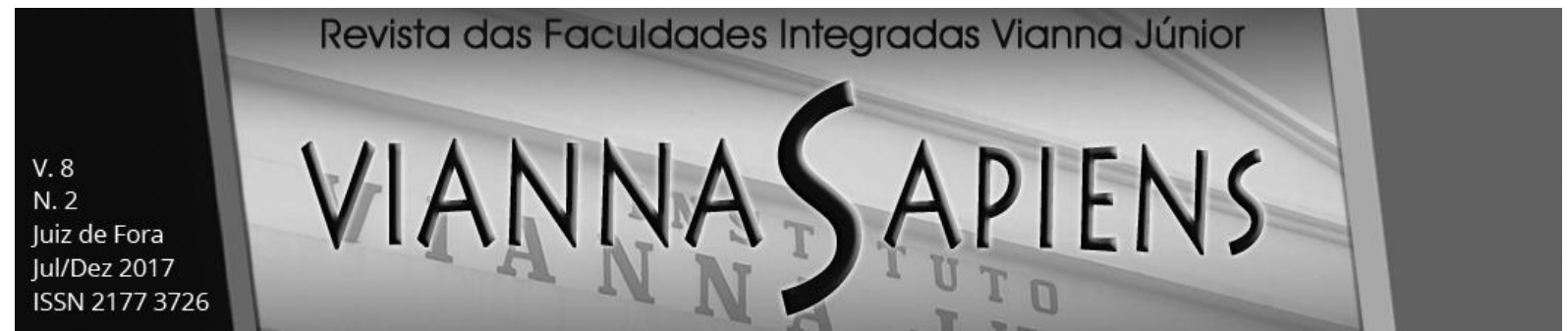

não se compreende a relação entre "judicialização da política e ativismo judicial", o que é incorreto (PEREZ, 2012).

Com a judicialização da saúde o Poder Judiciário passa a ter uma atuação mais política - movimento na busca da conformação dos objetivos constitucionais e da emancipação social - devendo, sempre que a integridade e eficácia de direitos fundamentais forem comprometidas, atuar no sentido de fazê-los valer e inclusive controlar os Poderes Executivo e Legislativo (CAMBI, 2009).

Além disso, Cambi (2009) assegura que quando se dá o que convenciona-se aqui chamar de "Desneutralização Política do Judiciário", por meio da judicialização de direitos, a função de julgador incumbida ao Poder ora mencionado não se refere mais somente a subsunção do fato à letra da lei positiva, mas se estende à uma análise do exercício do poder de legislar e administrar, identificando o alcance das finalidades impostas pela Constituição, e, se - somente se - houver um desvio na persecução destas finalidades, brota-se a possibilidade de uma atuação "socioterapêutica" do Judiciário, que poderá determinar a concretização dos preceitos constitucionais do Estado, alcançando a proteção dos Direitos Fundamentais.

Com isso, vê-se que o Judiciário não está mais restringido ao estrito legalismo, mas antes, é convidado a ser responsável, junto ao Legislativo e Executivo, pelo sucesso político das exigências do Estado, podendo implementar Direitos Sociais. Nessa orientação Warren ${ }^{5}$ explica que "os juízes da Corte Suprema do país devem ser não somente grandes juristas, senão também estadistas construtivos" (apud CAMBI, 2009, p. 196). Assim o Judiciário também é chamado a resolver problemas sociais relevantes como a saúde, por exemplo, ainda que de caráter político.

No mesmo sentido, Campos (2014), ao tratar da judicialização da política, afirma que desse fenômeno pode nascer o ativismo judicial. Assim, judicializar diz respeito a levar questões ao Judiciário, e, dependendo de sua postura, se pode ou não as resolver, nasce o ativismo ou o passivismo judicial. Dessa forma, o ativismo é fruto da judicialização, e, se os Tribunais se negassem a resolver os problemas a

\footnotetext{
${ }^{5}$ Jurista Estadunidense.
} 


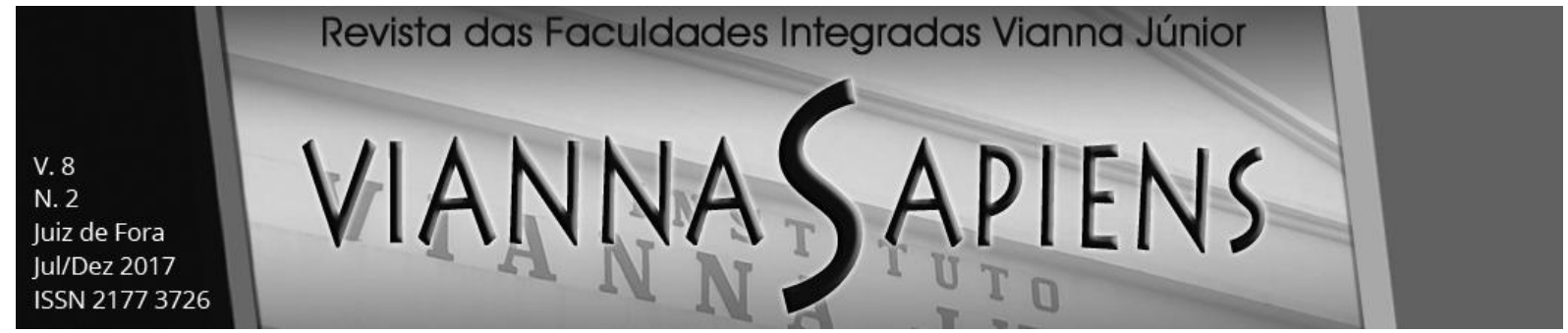

eles apresentados, em médio prazo essa conduta findaria o processo de judicialização.

É uma estrutura bem complexa, e olhando desta perspectiva, fica difícil defender a possibilidade de o Poder Judiciário consolidar o direito a saúde no Brasil, já que o seu resultado é o ativismo, porém Campos (2014, p. 149) observa que o ativismo, de fato bem criticado, é considerado apenas em sua dimensão negativa, afirmando que "para a maioria dos que se debruçam sobre o tema, os juízes ativistas são sempre uma ameaça aos valores democráticos e à separação dos poderes, de modo que o termo acaba servindo como substituto para excesso judicial".

Sendo assim, é brilhante a descrição de Campos, traduz a incoerência do sentido negativo amplamente vinculado ao ativismo judicial, confunde-se o posicionamento ativista do Judiciário com erros de excesso, aos quais até mesmo o Executivo e Legislativo, estão sujeitos e incorrem rotineiramente, por exemplo, no excesso de demora para a concretização de direitos. Além disso, Campos (2014, p. 149) complementa afirmando que "decisão ativista seria, na opinião majoritária, sinônimo de decisão arbitrária; juízes ativistas, os caras maus".

Não é bem assim. Voltando para a questão da "Desneutralização Política do Judiciário", é preciso afirmar que o ativismo judicial pode acontecer na busca pela implementação não só do direito à saúde, mas em relação a todos previstos na $\mathrm{CF} / 88$, e isto não viola o princípio da separação dos Poderes, nem mesmo o regime democrático, pois, considerando que para se praticar e tornar socialmente aceita uma postura ativista é preciso uma justificação razoável, assim como preceitua Rothenburg (2005), a não concretização do Direito Fundamental à saúde que se perfaz com os problemas estruturais do SUS já constitui justificativa mais que suficiente para tanto.

Impedir que o Judiciário implemente direitos sociais sob o argumento de ofender a separação dos Poderes é inaceitável para a realidade brasileira atual, a 


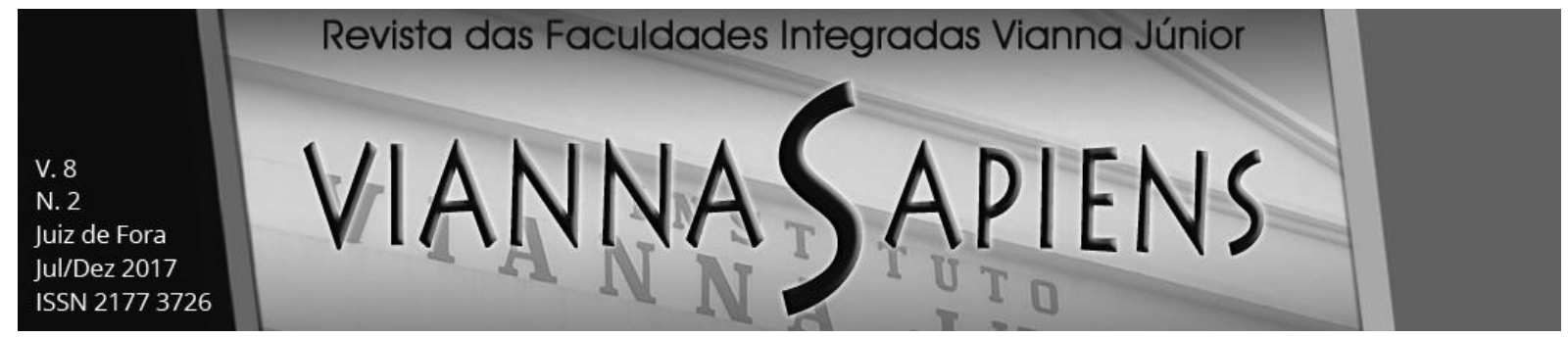

Teoria Clássica deste princípio idealizada por Montesquieu foi superada, ${ }^{6}$ como já dito, e a Constituição Federal de 1988 (CF/88) adota este princípio como arranjo institucional, mas ao mesmo tempo garante no Art. 5ํ, inciso XXXV, "que a lei não excluirá da apreciação do Poder Judiciário lesão ou ameaça a direito", bem como dispõe de remédios constitucionais para resguardar os Direitos Fundamentais, como o habeas corpus, mandado de segurança, mandado de injunção e habeas data, por exemplo. Em outros termos, cria um sistema de separação de Poderes e mecanismos que possibilitam o controle de atuação, o que inclui o desempenho do STF na defesa de Direitos Sociais previstos na CF/88, evento que acontece especialmente por meio do controle de constitucionalidade difuso, com a análise de recursos extraordinários.

Decorrente da judicialização não se pode admitir em tempos atuais é o passivismo, a conformação do Judiciário com as violações a Direitos Fundamentais como a saúde, aprovando esse tipo de comportamento que é incompatível com o modelo de Estado Constitucional, uma vez que a Constituição tem força vinculante, dirige a atuação do Executivo e Legislativo, não podendo ser inobservada. Assim, não se pode mais aceitar do Judiciário, especificamente do STF, condutas passivas como a de 1990, em que a Corte se calou diante de medidas políticas de intervenção econômica de caráter inconstitucional. Nesse diapasão, Campos (2014, p. 242, grifo nosso) salienta que:

O conjunto de reformas econômicas de março de 1990, dirigido a estabilizar a hiperinflação, conhecido como 'Plano Collor', foi contestado no Supremo, principalmente, quanto à medida de confisco de ativos financeiros da população. A corte protelou e, por razões processuais, acabou não julgando o mérito das demandas, deixando de interferir em medidas políticas de intervenção econômica de duvidosa constitucionalidade. Típico e equivocado uso das virtudes passivas.

\footnotetext{
${ }^{6}$ Até o modelo clássico previa exceções, assim como aponta Ferreira Filho (2009, p. 137) ao afirmar que: "O próprio Montesquieu abria exceção ao princípio da separação ao admitir a intervenção do chefe de Estado, pelo veto, no processo legislativo. A organização, todavia, dos três poderes na Constituição envolve sempre uma certa invasão de um poder na função reservada a outro".
} 


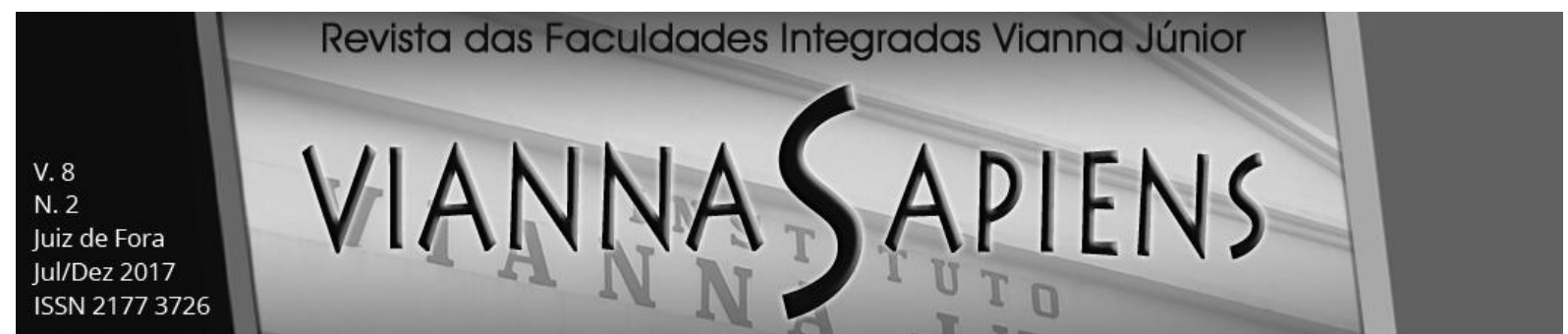

Com esse exemplo histórico, reforça-se que o STF não pode é abster-se esperando a boa vontade do Executivo e Legislativo na satisfação do direito à saúde, que podem atuar ou não, imediatamente ou não, não se sabe, o que a Constituição veda na verdade, é a ausência de serviços públicos de saúde - baseados na universalidade, isonomia e generalidade - de qualidade.

Alinha-se, portanto, à abordagem multidimensional do ativismo judicial feita por Campos (2014), de maneira especial em relação as dimensões estrutural e de direitos. No "ativismo judicial estrutural ou horizontal" remonta-se a atuação do STF diante dos demais Poderes institucionais, como ele se comporta diante das decisões tomadas por esses Poderes e como toma decisões por substituição (Desneutralização Política). Em outras palavras, todas as decisões importantes dos demais Poderes estão submetidas a um controle de constitucionalidade por parte do STF e na ausência de decisões que deveriam ter sido tomadas por esses Poderes a Corte Constitucional as toma de acordo com a Constituição.

A "dimensão ativista de direitos" está ligada à persecução de posições de liberdade, igualdade e dignidade, podendo o STF interferir na tutela de direitos e escolhas na concretização de Políticas Públicas. Dentro dessa dimensão encontram-se duas perspectivas: a negativa, tendo função regulatória, impondo ao Estado um dever de abstenção, de respeito a posições de direitos e garantias individuais, e de outro lado uma perspectiva positiva, que se traduz na exigência face ao Estado para cumprir deveres constitucionais, como a efetivação do direito à saúde, por exemplo, e outros mais deveres constitucionalmente estabelecidos, inclusive, o dever de legislar.

Rejeita-se, por fim, a dimensão do ativismo judicial que é a essencialmente antidialógica, que programa o STF como único e exclusivo intérprete da Constituição, não havendo rumos de constitucionalidade fora de sua interpretação. Essa dimensão cria um STF altamente voluntarista e desejoso por dar a última palavra sempre, sem nenhum tipo de diálogo com os outros Poderes e seus respectivos órgãos, ou até mesmo a sociedade civil. Essa face do ativismo é ilegítima e altamente 


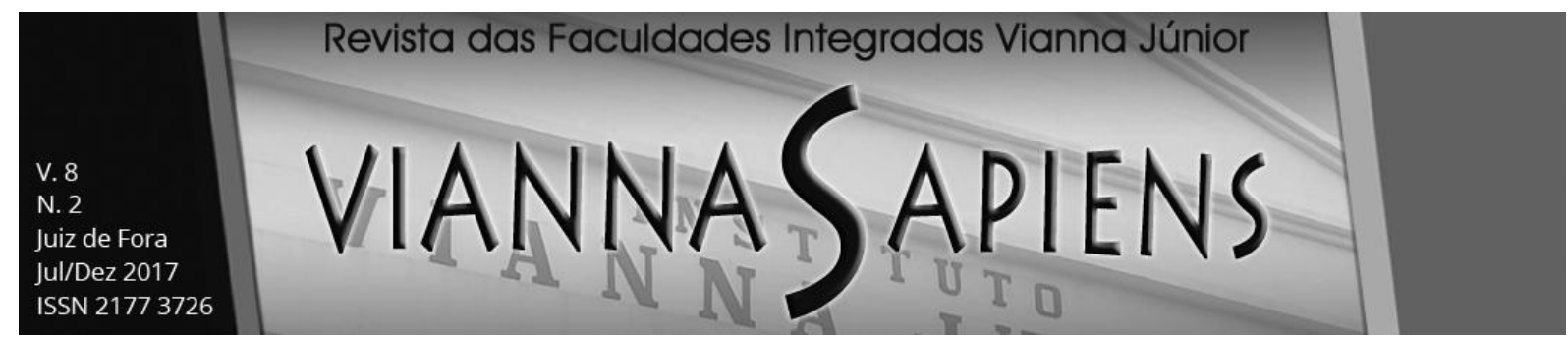

prejudicial ao Estado Constitucional, uma vez que todos são intérpretes da Constituição.

\section{DIREITO A SAÚDE E A JURISPRUDÊNCIA DO STF}

Feitas as considerações de caráter teórico, se debruça agora sobre a jurisprudência do Supremo Tribunal Federal (STF) em relação ao Direito Fundamental à saúde. Analisando o entendimento da Corte a partir da Arguição de Descumprimento de Preceito Fundamental (ADPF) n. ${ }^{\circ} 45$, da Audiência Pública em Saúde, e do Agravo Regimental (AgR) em Suspensão de Tutela Antecipada no 175, é que se compreende como se dá a atuação da Corte na concretização do direito à saúde. O processo metodológico de escolha e análise jurisprudencial toma estes referidos casos por considerá-los emblemáticos e paradigmáticos na atuação do STF no que tange o direito fundamental à saúde.

\subsection{Arguição de Descumprimento de Preceito Fundamental no 45}

A Arguição de Descumprimento de Preceito Fundamental (ADPF), foi proposta em detrimento do Presidente da República, que vetou o $§ 2^{\circ}$ do Art. 55 de proposta de Lei de Diretrizes Orçamentárias (LDO), que foi convertida na Lei 10.707, de 30 de julho de 2003, com objetivo precípuo de fixar diretrizes para a criação de lei orçamentária do ano seguinte, no caso 2004. Assim, o dispositivo vetado afirmava:

$\S 2^{\circ}$ Para efeito do inciso II do caput deste artigo, consideram-se ações e serviços públicos de saúde a totalidade das dotações do Ministério da Saúde, deduzidos os encargos previdenciários da União, os serviços da dívida e a parcela das despesas do Ministério financiada com recursos do Fundo de Combate à Erradicação da Pobreza.

O Partido da Social Democracia Brasileira (PSDB), na qualidade de autor da ação constitucional, sustentou que o veto violava diretamente disposições constitu- 


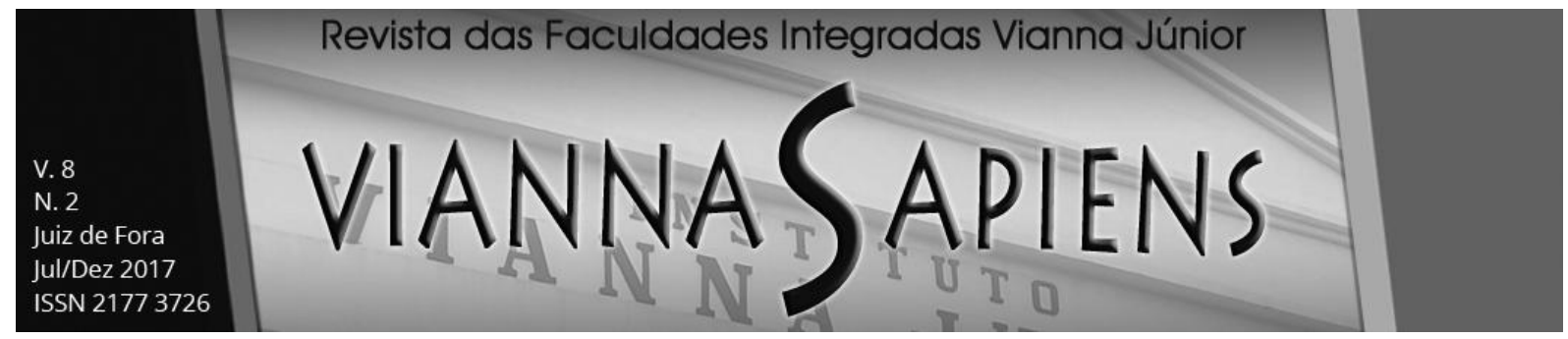

cionais, inseridas pela Emenda ํㅡㄹ, do ano 2000, que fixava as formas de arrecadação e consequentemente financiamento de gastos com saúde. Isso foi o suficiente para que o STF pudesse se posicionar em relação à intervenção na área de Políticas Públicas e efetivação de Direitos Fundamentais.

Desse modo, de acordo com o relator, Ministro Celso de Mello, o Poder Judiciário possui legitimidade para concretizar Políticas Públicas e satisfazer direitos, uma vez que constatada a abusividade governamental, explícita pelo veto, mas que posteriormente foi superada. Ademais, sobre a ação constitucional, o relator afirmou o reconhecimento da cabida ação constitucional como meio idôneo e apto a viabilizar a consolidação de Políticas Públicas. Ficou reconhecida ainda a dimensão política da jurisdição constitucional do Supremo, sendo que nos casos de inoperância dos Poderes Executivo e Legislativo, o Judiciário é também responsável pela implementação de Direitos e Políticas Públicas de cunho constitucional.

Ao tempo em que reconheceu a característica política da jurisdição constitucional, o ministro relator foi cauteloso e prudente afirmando que "certo que não se inclui, ordinariamente, no âmbito das funções institucionais do Poder Judiciário - e nas desta Suprema Corte, em especial - a atribuição de formular e de implementar Políticas Públicas" (MELLO, 2004, p. 01), deixando claro que o Judiciário só pode atuar quando demandado de forma extraordinária em casos de inequívoca violação ao texto Constitucional.

\subsection{Agravo Regimental na Suspensão de Tutela Antecipada no 175}

O Agravo Regimental foi proposto contra decisão da presidência do Supremo Tribunal Federal que indeferiu o pedido de Suspensão de Tutela Antecipada o 175 feito pela União em contraposição ao acórdão proferido pela $1^{\text {a }}$ Turma do Tribunal Regional Federal (TRF) da $5^{\mathrm{a}}$ Região, que garantiu o fornecimento do medicamento zavesca a uma paciente portadora de patologia nomeada niemann-pick tipo $c$, doença neurodegenerativa rara que provoca distúrbios neuropsiquiátricos, como movimentos involuntários, por exemplo. 


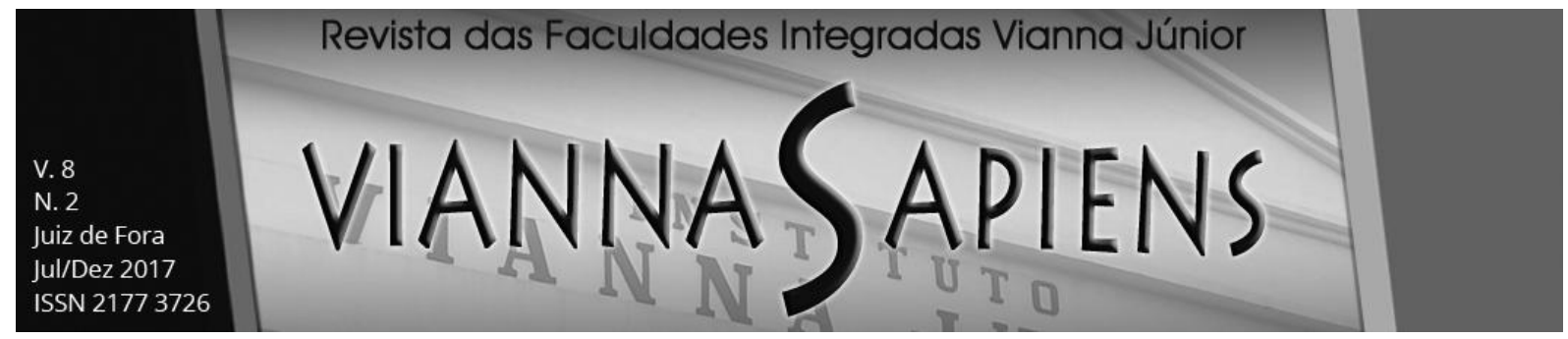

A fundamentação do agravo foi a violação ao princípio da separação dos Poderes, a incompetência do Judiciário para concretizar Políticas Públicas em dispensação de medicamento ante a inexistência da possibilidade de exame orçamentário na esfera jurisdicional, além da não existência de solidariedade nesses casos entre os entes federativos. A União sustentou ainda que, o mantimento da tutela antecipada gerava grave lesão ao orçamento público e à saúde coletiva.

No caso, o ministro relator Gilmar Mendes, votou contra o agravo, deixando clarificar o entendimento de que não há como o Estado se ausentar diante da necessidade de um administrado, que antes de tudo, é cidadão brasileiro e goza de todos os direitos previstos na Constituição. Rebateu ainda a tese da ilegitimidade passiva da União, ratificando o entendimento da Corte pela solidariedade no que se refere às obrigações públicas constitucionais, como é o caso.

Por fim, constatei que existem casos na jurisprudência desta Corte que afirmam a responsabilidade solidária dos entes federados em matéria de saúde e de que não cabe discutir, no âmbito do pedido de suspensão, questões relacionadas ao mérito da demanda (BRASIL, 2010, p. 77).

Vencido este argumento, Gilmar Mendes, em seu voto, passa a discutir as dimensões e implicações do Direito Fundamental à saúde dentro do contexto brasileiro. Para o ministro, da obrigação de intervenção, ou seja, da vinculação que o Estado possui na concretização desse direito, decorre também a proibição à defesa insuficiente. Dessa forma o Estado não pode se eximir da prestação de medicamentos - não só deles, mas de outros serviços de um modo geral - sob o argumento de já realizar Política Pública em saúde, como políticas de dispensação de medicamentos por exemplo, se a realiza de maneira ineficiente.

Segundo o voto proferido, uma aceitação da prestação dos serviços de saúde de forma insuficiente e a subordinação do direito fundamental discutido à dotação orçamentária o transforma em uma mera norma de caráter programático, tirando-Ihe o caráter fundamental, a aplicabilidade imediata, e, torna ineficaz a vinculação dos Poderes Públicos, desconsiderando-se o dirigismo constitucional, constituindo a 


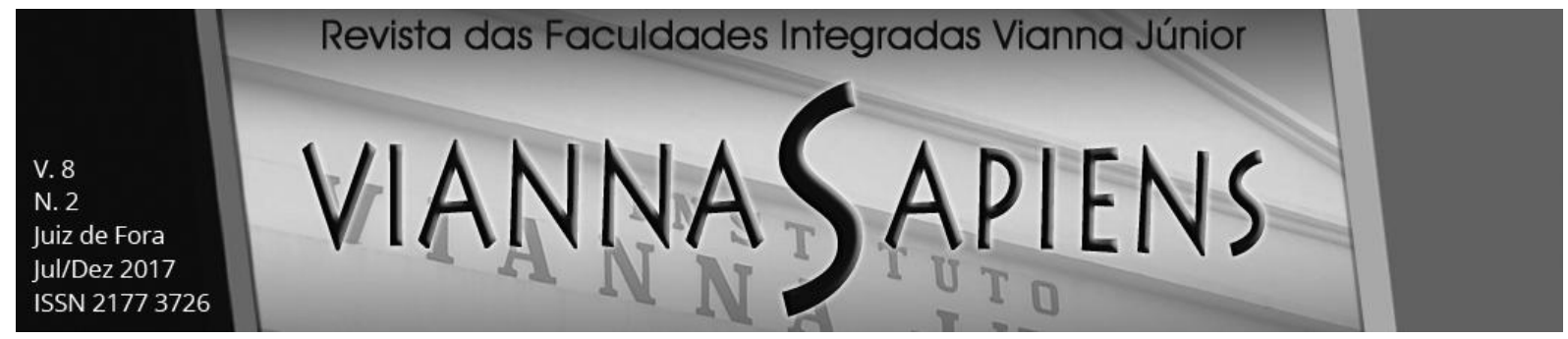

prestação de serviços em saúde um favor praticado pelo "bondoso" administrador, que dentro de sua discricionariedade resolve atuar (BRASIL, 2010). Sobre o aspecto orçamentário Gilmar Mendes assinala:

Em relação aos direitos sociais, é preciso levar em consideração que a prestação devida pelo Estado varia de acordo com a necessidade especifica de cada cidadão. Assim, enquanto o Estado tem que dispor de um determinado valor para arcar com o aparato capaz de garantir a liberdade dos cidadãos universalmente, no caso de um direito social como a saúde, por outro lado, deve dispor de valores variáveis em função das necessidades individuais de cada cidadão. Gastar mais recursos com uns do que com outros envolve, portanto, a adoção de critérios distributivos para esses recursos (BRASIL, 2010, p. 80).

É perceptível então que o Estado, representado pelo administrador público e do legislador, deve se preparar profundamente para ter Políticas Públicas eficientes e não usar a reserva do possível como justificativa da conduta omissiva em deixar de prestar assistência. Assim, é de se avultar que na afirmação do ministro fica clara a necessidade da adoção de critérios objetivos nesses casos extraordinários, o que não implica dizer que o direito não possa ser prestado. Por fim o Tribunal foi unânime, seguindo o relator, negando o provimento do agravo, sedimentando jurisprudência pacífica no sentido da possibilidade de conformação de Políticas Públicas de saúde.

\section{A JURISPRUDÊNCIA DO SUPREMO TEM ALGO A REVELAR?}

Ressalte-se que não é tarefa simples analisar a jurisprudência do Supremo Tribunal Federal (STF) dado o grande número de demandas as quais o Tribunal é provocado a decidir, os posicionamentos heterogêneos dos ministros que o compõem e consequentemente as variações no modo de julgamento. Desse modo, primeiramente, é necessário destacar que do ponto de vista metodológico foram escoIhidas a ADPF n. ${ }^{\circ} 45$ e o AgR na Suspensão de Tutela Antecipada n. ${ }^{\circ} 175$, datados 


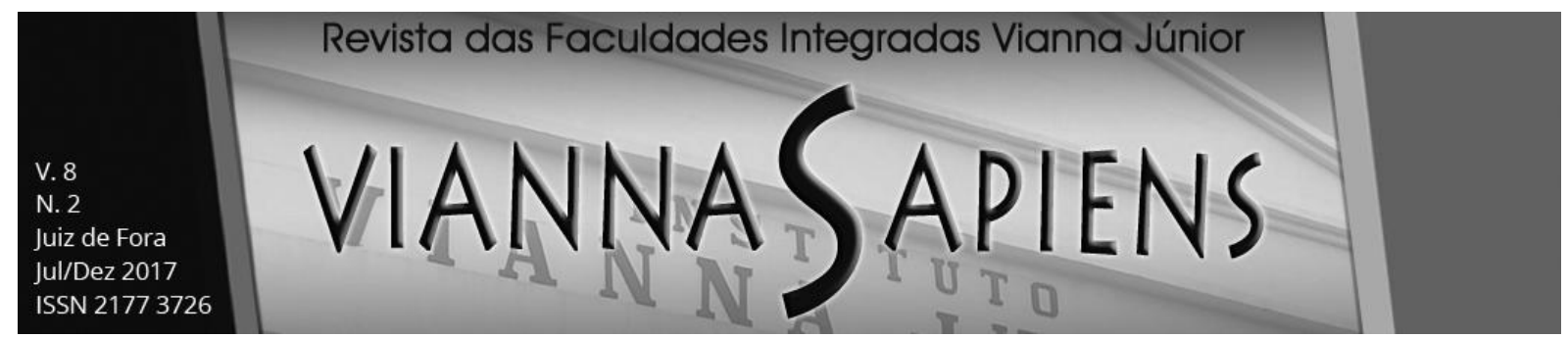

de 2004 e 2010 respectivamente, por serem decisões paradigmáticas do STF que funcionaram e funcionam até os dias atuais como referência no julgamento de ações que versam sobre o direito à saúde e neste estudo são ponto de partida para a observação do comportamento jurisprudencial dessa Corte.

Assim, a judicialização da saúde é um indício contundente de desconfiança dos cidadãos em relação ao Poder Executivo, responsável por implementar Políticas Públicas nas mais diversas áreas. Diante das inconstâncias e ineficiência de gestão por parte do Executivo, os administrados veem o Judiciário como via alternativa para a acesso a serviços de saúde (LEMOS, 2017), desde o fornecimento de remédios até procedimentos cirúrgicos. Desse modo, a desconfiança no Executivo, e logicamente confiança no Judiciário (TONELLI, 2013), pode ser constatada nas últimas décadas no Brasil, a partir da observação da quantidade de recursos que o Ministério da Saúde tem destinado para o cumprimento das decisões judiciais (LEMOS, 2017). Em 2005, o montante gasto com os serviços determinados via judicial, girava em torno de 2 milhões e meio, entre 2010 e 2014 o valor cresceu 500\% (COSTA, 2015), chegando a soma de 2,1 bilhões, e, em 2016 o gasto fora de 1,17 bilhão (SHALDERS, 2017).

Nesse aspecto, de acordo com Moisés (2010) e Lemos (2017), dois terços da população brasileira não acreditam em parlamentos, governos, política e serviços de saúde, segurança e educação. A desconfiança pode ser facilmente percebida quando o olhar se volta para as manifestações que ocorreram desde 2013 e a expressão de insatisfação da população com o Governo e sua administração.

Ademais, a imersão da maioria dos políticos brasileiros em um cenário de corrupção contribui para a desconfiança da população. Para além da desconfiança no Poder Executivo, que Lemos (2017, p. 413) considera como o fenômeno que "impulsionaria a judicialização", há igualmente o descontentamento com o Sistema Único de Saúde (SUS), fato demonstrado pela pesquisa do Instituto Datafolha (2016) anteriormente mencionada, bem como em outra pesquisa do mesmo instituto, datada de 2014, no qual $87 \%$ dos entrevistados demonstraram sua insatisfação com a saúde pública (DATAFOLHA, 2014). 


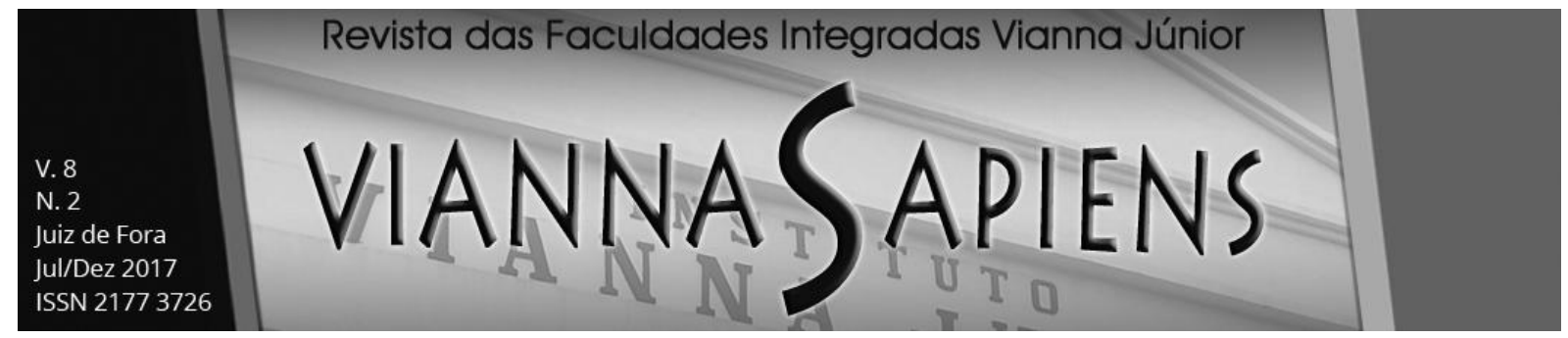

Sendo assim, atualmente o grande número de demandas judiciais no tocante ao direito à saúde no Brasil é a manifestação pura do descrédito e insatisfação da população com o Poder Executivo por meio do seu sistema público de saúde. Nesse caso, passa-se a examinar o modo comportamental do Supremo Tribunal Federal (STF) na seara do direito à saúde e Políticas Públicas. A princípio o que se extraí da Arguição de Descumprimento de Preceito Fundamental (ADPF) n. ${ }^{\circ} 45$, e, do julgamento do Agravo Regimental (AgR) em Suspensão de Tutela Antecipada n. ${ }^{\circ}$ 175, é que o STF não define "o que decidir", não se imiscuí em questões materiais, o que caracterizaria no entendimento de Travassos (2015) o maximalismo judicial.

Assim, os julgamentos paradigmáticos trazidos à baila revelam antes um posicionamento minimalista do STF. Travassos (2015, p. 650) define como minimalista "a técnica decisional [...] que os órgãos judiciais [utilizam], quando da solução de conflitos" quando decidem "tão somente o estritamente necessário para a solução satisfatória do caso em questão". Em outras palavras, o Supremo Tribunal Federal, decidiu nas decisões paradigmáticas expostas anteriormente, que a decisão judicial deve ser mínima e suficiente para dar provimento satisfatório aos pedidos que lhe são formulados. Observa-se que tanto na ADPF n. ${ }^{\circ} 45$, de controle concentrado, como no $\mathrm{AgR} \mathrm{n} .^{\circ} 175$, oriunda do controle de constitucionalidade difuso, a Corte não definiu qual seria a melhor forma de gerir o orçamento público ou o melhor medicamento para o caso concreto, o que se depreende dos acórdãos é que o STF reconheceu o seu caráter político no sentido de poder concretizar Políticas Públicas de saúde, políticas estas existentes previamente em relação as demandas levadas ao Judiciário, que decide minimamente pela concessão dos pedidos e obriga por meio de decisão judicial o Executivo a cumprir a Política Pública ineficiente que viola os preceitos constitucionais.

Ainda no caso da ADPF n. ${ }^{\circ} 45$, sob o pretexto de que o STF interferiria em tese no orçamento público, a interferência não se daria por simples deliberação da Corte Constitucional, mas antes pela própria determinação normativa introduzida no ordenamento jurídico brasileiro pela Emenda Constitucional n. ${ }^{\circ} 29$, no que toca a 


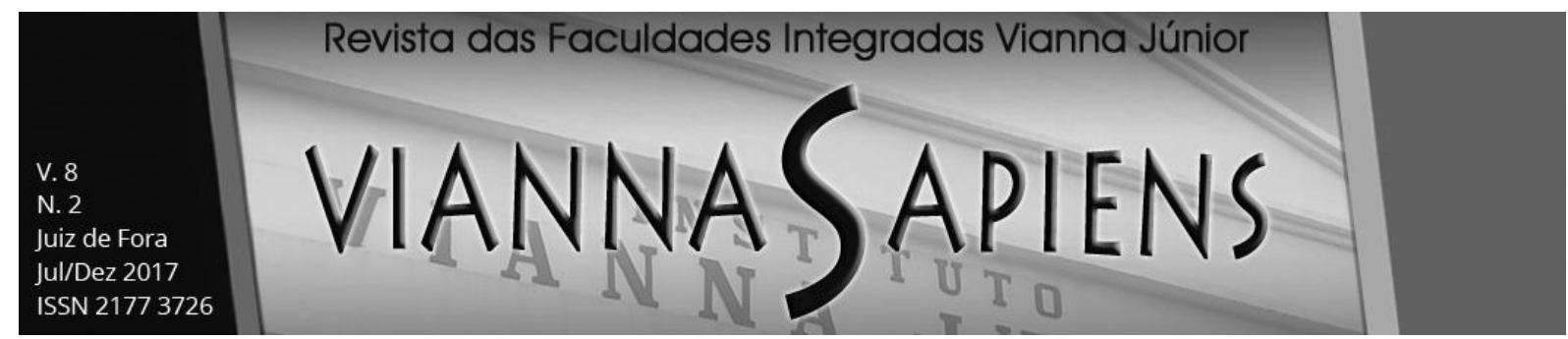

existência de um valor determinado a ser gasto com saúde, afetado pela Lei de Diretrizes Orçamentária (LDO), então objeto do controle de constitucionalidade.

O minimalismo judicial praticado pelo STF, é uma tendência que gera um consenso em meio a uma grande dificuldade teórica e legal. Muitos podem divergir sobre a fundamentação do direito à saúde, seus limites, a própria função do Poder Judiciário, o que seria político e o que seria jurídico, qual a linha que divide as questões judiciais de questões políticas. Enfim, uma infinidade de problemas a serem respondidos, mas que se respondidos no âmbito processual pode findar por de fato inserir a decisão judicial em matéria que não é competência do Judiciário, e, igualmente, não oferece a solução devida.

Exemplos de casos em que o STF profere decisões minimalistas são facilmente encontrados nos frequentes casos que envolvem Políticas Públicas de saúde, ${ }^{7}$ verifica-se inclusive que as decisões proferidas pela Corte de fato seguem a orientação firmada pelas decisões paradigmáticas abordadas especificamente nesta pesquisa. Do posicionamento minimalista do STF no que se reporta a saúde e as Políticas Públicas desta área é possível depreender algumas implicações positivas para o ordenamento jurídico. Além da possibilidade de formulação de um consenso (de que a Política Pública de saúde deve ser consolidada), as decisões minimalistas do Supremo auxiliam na formulação de uma relação de identificação entre casos decididos e casos que virão a ser decididos.

É positiva igualmente o reforço que decisões minimalistas dão ao zelo para com a estabilidade e a segurança jurídica (TRAVASSOS, 2015). A jurisprudência do STF cria na população brasileira uma expectativa de segurança, adotando uma postura minimalista o Tribunal então tonifica a segurança jurídica evitando rupturas abruptas no seu comportamento jurisprudencial.

\footnotetext{
7 Nesta orientação consultar os seguintes acórdãos proferidos pelo STF: RE $818572 \mathrm{AgR} / \mathrm{CE}$, Rel. Min. Dias Toffoli, j. 02.09.2014. Al 822882 AgR/MG, Rel. Min. Luis Roberto Barroso, j. 10.06.2014.
} 


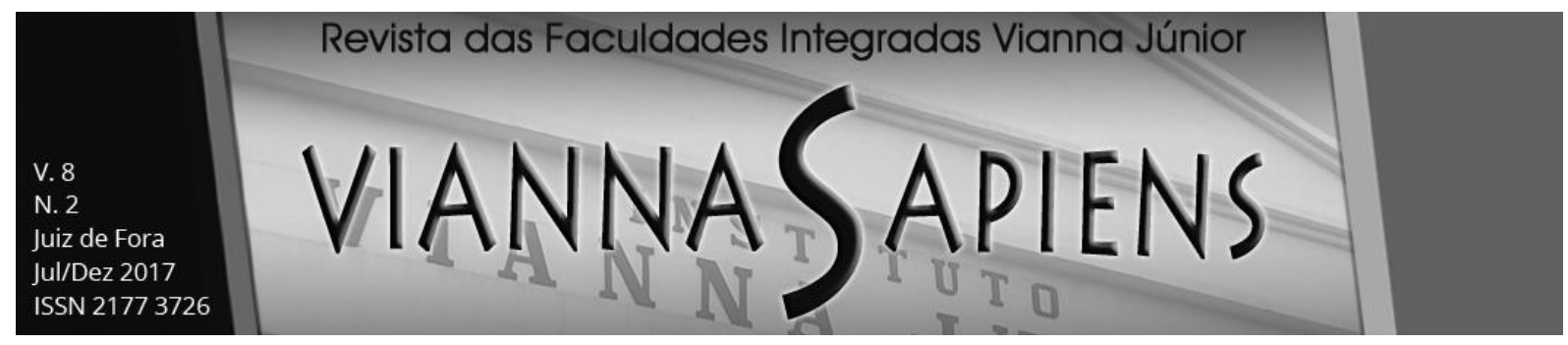

\section{A EMENDA CONSTITUICIONAL $\mathbf{N}^{\circ}$ 95: A FLAGRANTE INCONSTITUCIONALIDADE E A PROIBIÇÃO AO RETROCESSO SOCIAL}

Em outro prisma, os poderes Executivo e Legislativo, que já contam com certa desconfiança por parte dos cidadãos, vêm caminhando no sentido de agravar, ainda mais, o abismo social em que o país se encontra. Em junho de 2016, na tentativa de amenizar o déficit primário das contas públicas, foi apresentada na Câmara dos Deputados uma Proposta de Emenda Constitucional (PEC) de ㄲo 241 - que ao seguir para o Senado Federal teve a alteração de seu número, para 55 - para limitar os gastos públicos.

Segundo o governo brasileiro, o objetivo da PEC é "reverter, no horizonte de médio e longo prazo, o quadro de agudo desequilíbrio fiscal em que nos últimos anos foi colocado o Governo Federal" (BRASIL, 2016). Aprovada, a então Emenda Constitucional n. ${ }^{\circ} 95$, o valor a ser destinado aos setores sociais equivale ao valor gasto no ano anterior, com cifras corrigidas pela inflação. A medida vincula os três poderes da União: Executivo, Legislativo e Judiciário.

Foram muitos os argumentos utilizados pelo governo a favor da chamada "PEC do teto de gastos". O Ministro da Fazenda do governo Michel Temer, Henrique Meirelles, membro convidado a participar da Comissão Especial da PEC, afirmou que contendo os gastos públicos, a medida ajudaria a recuperar a confiança no mercado, a gerar mais emprego e renda (BRASIL, 2016). Citou algumas experiências internacionais de países que adotam regras de controle de gasto, como Austrália, Canadá, Dinamarca, Estados Unidos, França, Peru e Suécia.

Ocorre que a realidade em países desenvolvidos é diametralmente oposta da situação econômico-social em que se encontra o Brasil, especialmente pós impeachment. Sendo assim, a partir da iniciativa em implementar um novo regime fiscal, algumas teses devem ser confrontadas, como, em particular, de que modo a mencionada PEC, agora emenda, prejudica os esforços realizados nos últimos anos a fim de se resguardar a implementação de Políticas Públicas no setor da saúde, sen- 


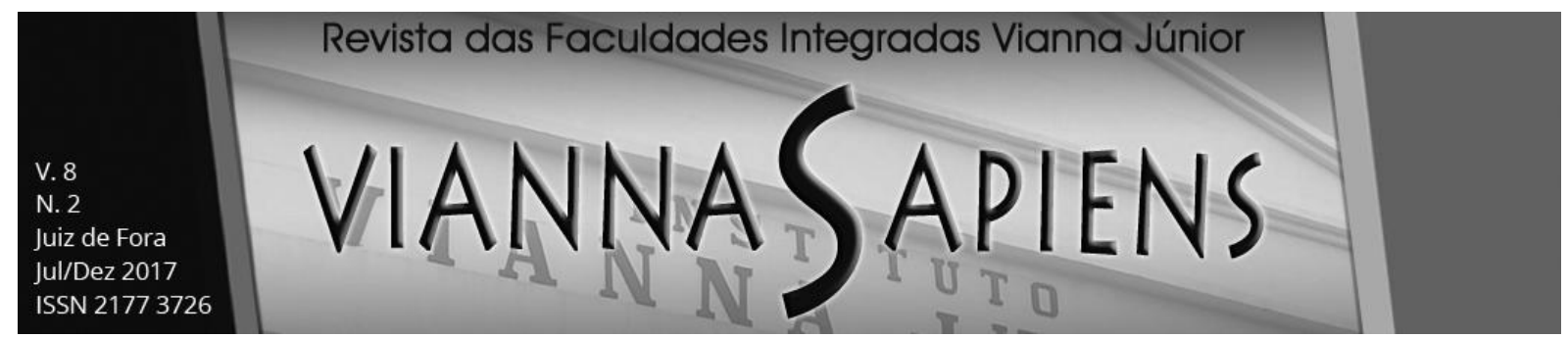

do, portanto, medida que afronta diretamente princípios constitucionais e garantias fundamentais.

Primeiramente, mister faz-se ressaltar que com a aprovação da proposta não é permitido o crescimento das despesas totais do governo acima da inflação, e, a impossibilidade de destinar às áreas sociais valores maiores que o do exercício financeiro anterior provocará, em curto prazo, uma defasagem nos valores reais. $\mathrm{E}$ ainda, para que seja possível aumentar os investimentos em determinada área, como por exemplo a saúde, só será possível se for alocado os recursos de outras demandas, como os destinados à educação pública. E ainda que o país retome os triIhos de uma economia em progresso, os próximos governantes perderão a autonomia sobre o orçamento.

Conforme fora demonstrado ao longo deste estudo, já não se tem uma prestação satisfatória dos Direitos Sociais por parte do Estado. No âmbito constitucional, em virtude de sua associação com o direito à vida, o direito à saúde constitui-se, ainda, como uma cláusula pétrea, não podendo ser excluído o resguardo que lhe foi alcançado pela Carta Constitucional e pelas legislações posteriores. Sua inclusão no rol das cláusulas pétreas é meio de impedir que seja suprido, bem como de assegurar a promoção e o atendimento dos objetivos constitucionais (PULIDO, 2008).

E ao analisar a saúde, direito público subjetivo, oponível individual e coletivamente ao Estado, a omissão diante do facere estatal quanto à garantia de prestação de Políticas Públicas e promoção de sua universalidade faz com que medidas austeras, como a limitação do crescimento real dos gastos públicos vá de encontro ao princípio da aplicação progressiva dos Direitos Sociais. Como principal argumento de rechaça à aprovação do novo regime fiscal engendrado pelo governo, podemos mencionar a impossibilidade de retroceder na prestação de Políticas Públicas sociais de caráter essencial, como é o caso da saúde. É aqui que se descortina um princípio de inspiração alemã: a proibição do retrocesso social.

Tendo sua origem na Alemanha, em meados dos anos de 1970, a fórmula protetiva dos direitos fundamentais, inicialmente denominada Teoria da Irreversibilidade dos Direitos Fundamentais, vincula os Estados federados ao princípio do Esta- 


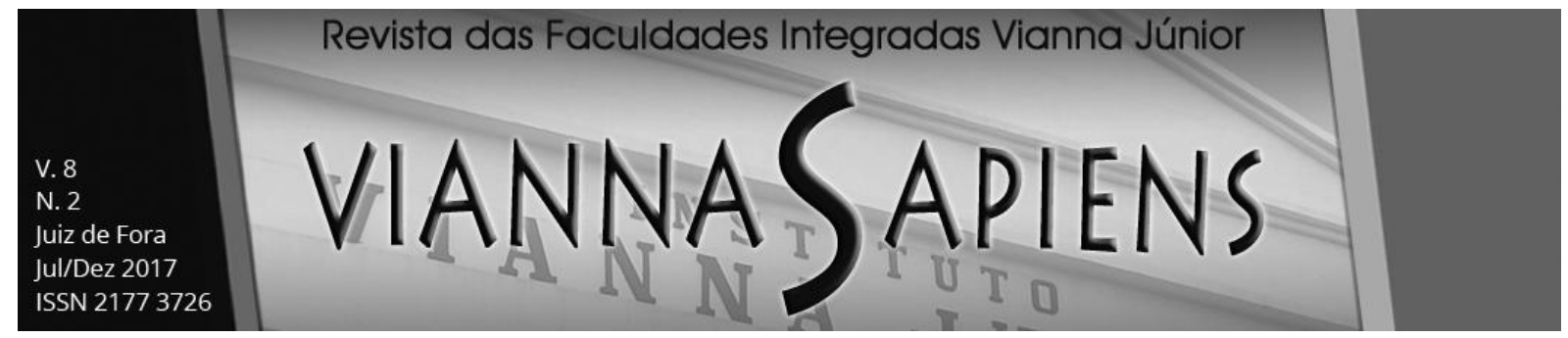

do de Direito Social, de modo a impedir retrocessos que afetem seu conteúdo essencial, ou seja, sua natureza jusfundamental (NOVAIS, 2010).

Conforme preleciona Sarlet (2009), a expressão do princípio em tela seria em relação à atuação, principalmente, do legislador e do administrador, não sendo possível a supressão de Direitos Fundamentais, independentemente de sua natureza social. Sendo defesa a concretização de normas cogentes que limitem a sua eficácia.

Diversas entidades manifestaram-se contra a proposta de emenda, destacando-se as Universidades e Instituições de Ensino Federais e a Associação Brasileira de Saúde Coletiva (ABRASCO). Muitas foram as ocupações em escolas públicas e campus universitários em ato contra a proposta do governo, e a ABRASCO expressou sua indignação divulgando carta pública, onde afirmou que a proposta pode sucatear o Sistema Único de Saúde (SUS), utilizado principalmente pela população de baixa renda que não dispõe de plano de saúde (ABRASCO, 2016).

É importante ressaltar que a judicialização da saúde e o posicionamento minimalista do STF, não reflete apenas no orçamento e órgãos públicos, uma vez que a demanda também é crescente no que concerne aos planos privados de saúde. A intento, no dia 19 de setembro do 2017, a Comissão de Assuntos Sociais (CAS) promoveu uma audiência pública com representantes do governo e das operadoras de planos de saúde Amil, Sul América e Geap. A pauta da audiência versou, principalmente sobre os reajustes realizados pelas operadoras nos planos contratados. A justificativa fornecida pelo presidente da Associação Brasileira de Medicina de Grupo (ABRAMGE) foi o impacto das progressivas demandas judiciais que recaem nos planos de saúde. Os representantes alegaram que é necessário o reajuste para que se estabeleça um nível de equilíbrio financeiro, e que os custos com a judicialização são divididos por todos (BRASIL, 2017).

E então, chega-se ao desfecho: se para a iniciativa privada é preciso mais recursos financeiros para a efetivação do direito à saúde tutelado judicialmente, para assegurar a prestação estatal de um mínimo de Políticas Públicas no âmbito da saúde, de modo a não promover um retrocesso social nas conquistas adquiridas com a 


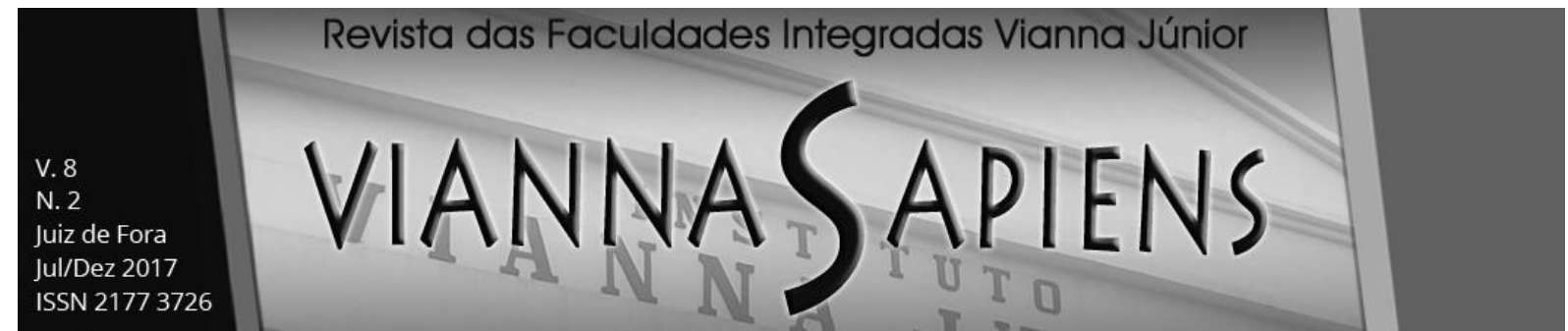

atuação positiva da Suprema Corte, como irá o governo reduzir os recursos atualmente disponíveis, se hodiernamente permanecem insuficientes? Logo, resta evidente a controvérsia sobre a constitucionalidade de uma emenda à Constituição, como é a de n. ${ }^{\circ}$ 95. Colaborando para uma situação, no mínimo, incompreensível para um Estado de bem-estar social.

A Organização para Cooperação e Desenvolvimento Econômico (OCDE), em 2015, constatou que o valor per capita gasto com saúde no Brasil é inferior em relação aos países com indicadores sociais mais desenvolvidos, como Espanha, Portugal e Eslovênia. A OCDE, fez recomendações para que os recursos em saúde fossem aumentados progressivamente nos próximos anos, permitindo assim o aumento de serviços de saúde, formação de recursos humanos e implementação de especialidades (OCDE, 2015).

Efetivamente, a Emenda Constitucional n. ${ }^{\circ}$ 95, viola o princípio do não retrocesso social, atingindo diretamente a condição material, - saúde -, fundamental e indispensável para a fruição dos direitos de liberdade, política e cidadania. É medida que afeta em alto grau a população brasileira mais pobre. O país retrocedeu constitucionalmente, e, logo os efeitos serão sentidos se consideramos a tendência do crescimento da população.

\section{CONCLUSÃO}

Diante o exposto, resta claro que a Teoria Clássica da Separação dos Poderes, conforme desenhada por Montesquieu, fora superada na contemporaneidade, não funcionando mais como uma divisão cerrada e exausta das funções de cada Poder. No Brasil a Teoria da Separação dos Poderes é tomada pela Constituição Federal de 1988 (CF/88), como arranjo de estruturação institucional dos Poderes, devendo neste contexto o Executivo, Legislativo e Judiciário desempenharem suas funções com fulcro nas competências previstas na disciplina constitucional e também estando sujeitos ao controle recíproco de seus atos. 


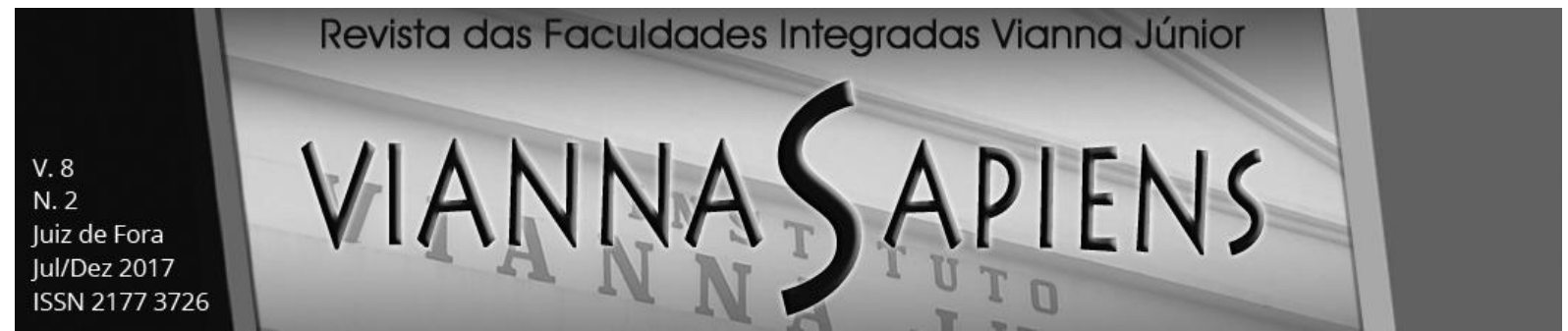

No aspecto do direito à saúde e suas respectivas Políticas Públicas, não restam dúvidas acerca da possibilidade de o Poder Judiciário atuar em substituição aos Poderes políticos originariamente competentes na concretização de direitos. É o fenômeno chamado de "Desneutralização Política do Poder Judiciário", quando este poder é chamado a proteger direitos e garantias individuais face a omissão e negligência dos Poderes políticos, desempenhando função socioterapêutica, corrigindo lesões e ameaças à direitos que acabam por violar os mandamentos constitucionais.

Se considerada a judicialização da saúde e o ativismo judicial - "Desneutralização Política do Judiciário" - como seu resultado é preciso compreender que atitudes ativistas podem e devem ser consideradas com respeito, o Judiciário não pode ter uma conduta "passivista" em relação às necessidades sociais que urgem e chegam a seu conhecimento enquanto via alternativa para a consolidação de Direitos Fundamentais, em especial o STF que é o guardião da Constituição.

Ressalte-se neste momento que a única decisão ativista que não se pode aceitar é a advinda de uma dimensão antidialógica, onde somente o Poder Judiciário, de maneira particular o STF, funciona como instância de interpretação constitucional, dando então a última palavra em temas extremamente relevantes para o Estado.

Assim, diante da análise de decisões paradigmáticas, como a Arguição de Descumprimento de Preceito Fundamental (ADPF) n. ${ }^{\circ} 45$, e, o Agravo Regimental $(\mathrm{AgR})$ em Suspensão de Tutela Antecipada $\mathrm{n} .{ }^{\circ} 175$, o que se infere à luz do debate teórico desenhando anteriormente é que o Supremo Tribunal Federal (STF), firma o entendimento de que o Judiciário pode atuar concretizando Direitos Sociais, no caso em tela o direito à saúde e Políticas Públicas decorrentes.

Dessa maneira, o grande número de ações judiciais envolvendo Políticas Públicas de saúde, apontam para a desconfiança da população em relação ao Poder Executivo, e, também, ao Sistema Único de Saúde (SUS). A experiência negativa com a gestão dos serviços públicos de saúde, como explicitado pelas pesquisas demonstradas pelo Instituto Datafolha, leva o fenômeno da judicialização à um patamar bastante significativo. O Judiciário passa a ser atualmente no Brasil, de forma alternativa, a arena mais segura para a efetivação de Direitos Fundamentais. 


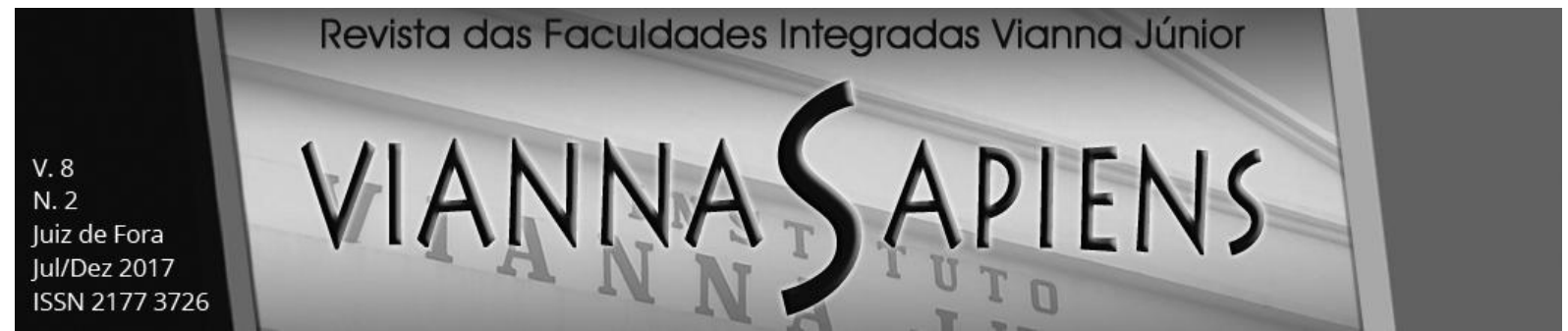

Nas decisões tratadas neste estudo, conclui-se que o STF não inseriu sua decisão no âmbito material do direito à saúde, determinando de que forma o direito poderia ser aplicado a partir da formulação de Políticas Públicas ou qual o medicamento mais adequado, por exemplo. A Corte não detém uma postura maximalista, mas antes se ateve ao que fora pedido nas demandas, decidindo minimamente para alcançar o consenso e uma rápida solução correta para os casos concretos que julgou. O comportamento jurisprudencial do STF, tem sido no sentido minimalista conforme se constata nas decisões mais recentes e posteriores aos casos emblemáticos estudados neste escrito - aos quais o leitor é remetido por intermédio da nota de rodapé $n^{0} 4$.

A atuação minimalista do Supremo, possui inclusive implicações positivas no ordenamento jurídico brasileiro pois cria consenso - de que o direito a saúde deve ser implementado - em meio a diversidade de questões problemáticas envolvendo o direito à saúde e a possibilidade de conformação pelo Judiciário, permitindo a coerência entre casos julgados e casos a serem decididos futuramente, aumentando a margem de segurança jurídica no que toca a efetivação do direito à saúde.

É positiva ainda se considerada a limitação dos gastos públicos instalada pela Emenda Constitucional n. ${ }^{\circ}$ 95, pois com a ausência de um aumento real com despesas em saúde, violando assim a vedação ao retrocesso social, o Judiciário continuará a ser o palco de decisionismo em questão de saúde, reestabelecendo a autoridade constitucional.

Portanto, finaliza-se este estudo, compreendendo com base na discussão teórica e na jurisprudência do STF, que o Judiciário pode conformar Políticas Públicas de saúde em substituição ao Poder político responsável originariamente por tal missão, desde que seja constatada a omissão e negligência para com os preceitos constitucionais que configuram o direito à saúde enquanto fundamental. Substituição que tende a se legitimar cada vez mais dado o inexistente crescimento real de despesas em saúde inaugurado pelo novo regime fiscal.

O grande volume de ações judiciais no solo da saúde indica a desconfiança nas instituições públicas responsáveis pela concretização do direito ora discutido. E 


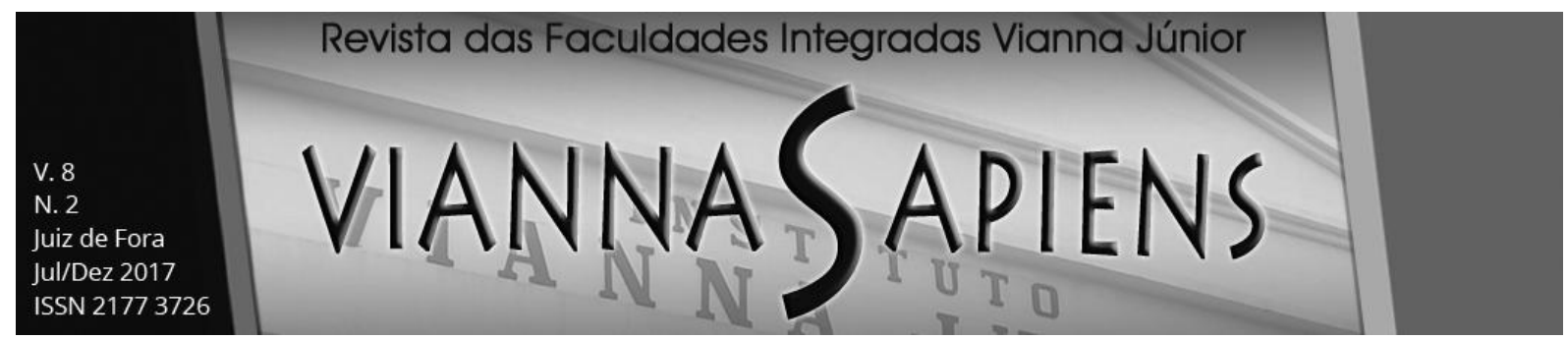

o comportamento minimalista do STF em nada interfere em questões estritamente políticas, mas preza pela guarda da Constituição, função primariamente sua.

\title{
JUDICIALIZATION OF THE RIGHT TO HEALTH AND JURISPRUDENTIAL BEHAVIOR OF THE SUPREME FEDERAL COURT
}

\begin{abstract}
Health was recognized in the 1988 Constitution as a social right and should be implemented through social and economic policies. In this context, this article addresses the judicialization of health in post-88 Brazil. It aims to analyze the possibility of the judiciary to implement the right to health through the implementation of public policies, identifying the understanding that remains clarified in the jurisprudence of the STF and what this revealed in the Brazilian context. The methodological approach of the writings is essentially qualitative, supported by bibliographic and documentary research techniques. From the study carried out, it is inferred that the Judiciary can realize the right to health against the omission of the responsible political Powers, primarily restoring constitutional authority. The jurisprudence of the Supreme is pacific in this orientation, and can be characterized by a minimalist action. Finally, it is pointed out that the tendency is for the judiciary to become even more active given the new fiscal policy of the State.
\end{abstract}

KEYWORDS: FUNDAMENTAL RIGHTS. PUBLIC POLICY. JUDICIARY. 


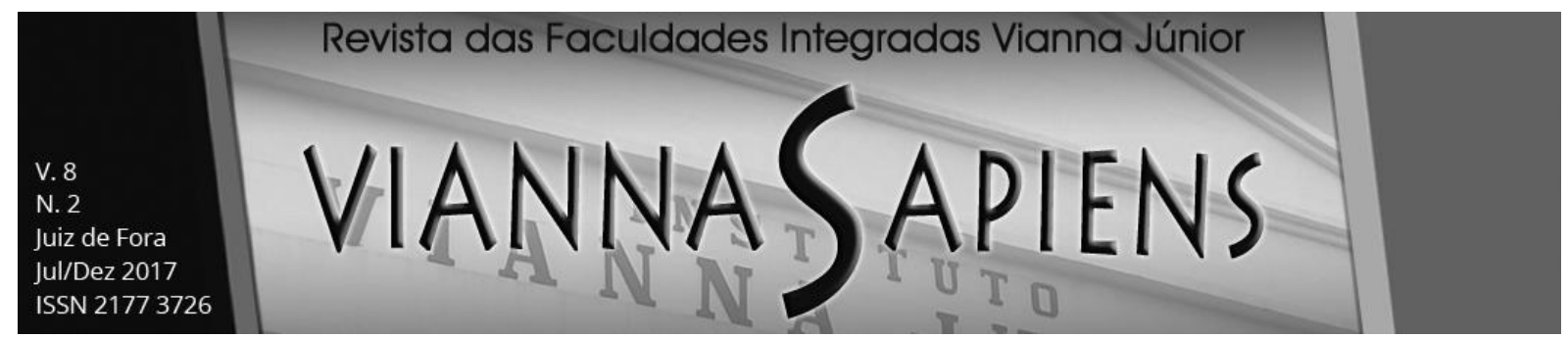

\section{REFERÊNCIAS}

ABRASCO. Carta Aberta Abrasco. Contra a PEC 241, em defesa do SUS, dos Direitos Sociais e da Democracia. 2016. Disponível em:

$<$ https://www.abrasco.org.br/site/noticias/institucional/carta-aberta-abrasco-contra-apec-241-em-defesa-do-sus-dos-direitos-sociais-e-da-democracia/20711/>. Acesso em: 28 set. 2017.

ARAÚJO, J. P. Guia dos direitos sociais: a igualdade social e as diferenças entre a esquerda e os neoliberais. São Paulo, SP: Editora Fundação Perseu Abramo, 2009.

BARROSO, Luís Roberto. Curso de Direito constitucional contemporâneo: os conceitos fundamentais e a construção do novo modelo. São Paulo, SP: Saraiva, 2009 .

Judicialização, ativismo judicial e legitimação democrática. Disponível em: <http://www.oab.org.br/editora/revista/users/revista/1235066670174 218181901.pdf>. Acesso em: 27 set. 2017.

BRASIL. Constituição. Constituição da República Federativa do Brasil de 1988. Disponível em: <http://www.planalto.gov.br/ccivil_03/Constituicao/Constitui\%C3\%A7 ao.htm>. Acesso em: 28 set. 2017.

Lei n. $^{\circ} \mathbf{1 0 . 7 0 7}$, de 30 de julho de 2003. Dispõe sobre as diretrizes para a elaboração da lei orçamentária de 2004 e dá outras providências. DOU: 31.7.2003.

. Câmara dos Deputados. Proposta de emenda à Constituição: PEC 241A. 2016. Disponível em: <http://www.camara.gov.br/proposicoesWeb/ prop_mostrarintegra? codteor $=1496778 \&$ filename $=S B T+3+P E C 24116+\% 3 D \% 3 E+P C$ +241/2016>. Acesso em: 28 set. 2017. 


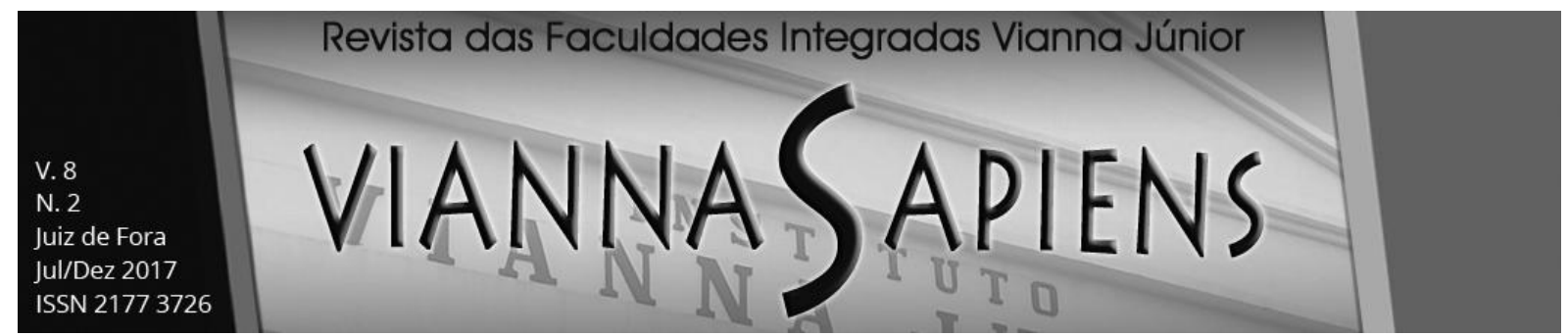

Senado Federal. Custos com judicialização são divididos por todos, dizem representantes de planos de saúde. 2017. Disponível em:

$<$ http://www12.senado.leg.br/noticias/materias/2017/09/20/custos-com-judicializacaosao-divididos-por-todos-dizem-representantes-de-planos-de-saude>. Acesso em: 28 set. 2017.

Supremo Tribunal Federal. Agravo regimental na suspensão de tutela antecipada no 175 - Ceará. Relator: Ministro Gilmar Mendes. 2010. Disponível em: <http://redir.stf.jus.br/paginadorpub/paginador.jsp?docTP=AC\&doclD=610255>. Acesso em: 26 set. 2017.

Supremo Tribunal Federal. Audiência pública em saúde. Disponível em: $<$ http://www.stf.jus.br/portal/cms/verTexto.asp?servico=processoAudienciaPubliaSau de\&pagina=Cronograma $>$. Acesso em: 27 set. 2017.

Supremo Tribunal Federal. Arguição de descumprimento de preceito Fundamental - 45/DF. Relator: Min. Celso de Mello. 2004. Disponível em: <http://www.sbdp.org.br/arquivos/material/343_204\%20ADPF\%202045.pdf>. Acesso em: 27 set. 2017.

CAMBI, Eduardo. Neoconstitucionalismo e neoprocessualismo: Direitos Fundamentais, Políticas Públicas e Protagonismo Judiciário. São Paulo, SP: Editora RT, 2009.

CAMPOS, Carlos Alexandre de Azevedo. Dimensões do ativismo judicial do STF. Rio de Janeiro, RJ: Forense, 2014.

CARDOSO, Henrique R. O paradoxo da judicialização das Políticas Públicas de saúde no Brasil: um ponto cego do Direito? Rio de Janeiro, RJ: Lumen Juris, 2017.

COSTA, Amanda. Em cinco anos mais de 2,1 bilhões foram gastos com ações judiciais. 2015. Disponível em: <http://portalsaude.saude.gov.br/index.php/ cidadao/principal/agencia-saude/20195-em-cinco-anos-mais-de-r-2-1-bilhoes-foramgastos-com-acoes-judiciais>. Acesso em: 28 set. 2017. 


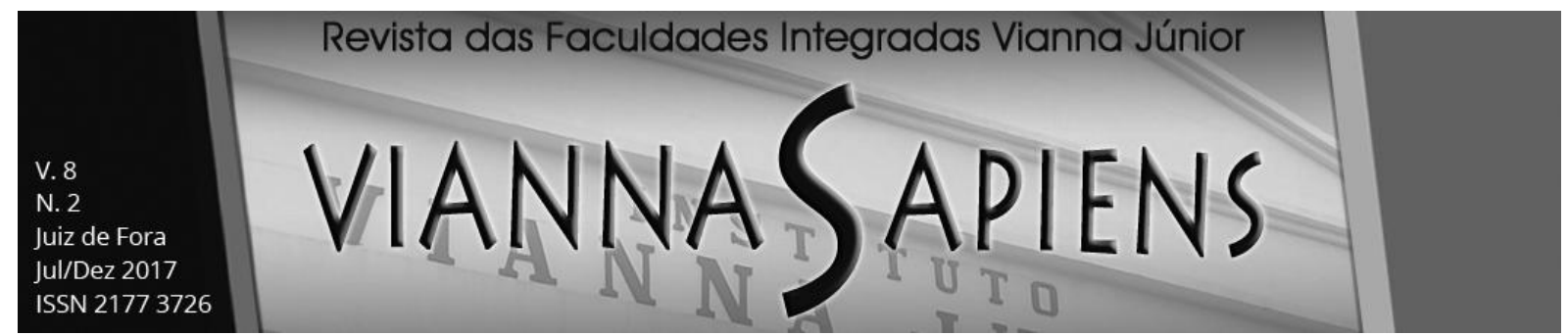

DATAFOLHA. Opinião dos brasileiros sobre o atendimento na área de saúde.

São Paulo, SP: Instituto Datafolha, 2014. Disponível em:

<http://portal.cfm.org.br/images/PDF/apresentao-integra-datafolha203.pdf>. Acesso em: 29 set. 2017.

Percepção dos brasileiros sobre a confiança e credibilidade em profissionais e instituições. São Paulo, SP: IPD, 2016.

FERREIRA FILHO, Manoel Gonçalves. Curso de Direito Constitucional. 35. ed. São Paulo, SP: Saraiva, 2009.

LEMOS, Junia C. A judicialização da saúde como sintoma da desconfiança no Poder Executivo. In: BUCCI, Maria P. D.; DUARTE, Clarice S. (Orgs). Judicialização da saúde: a visão do Poder Executivo. São Paulo: Saraiva, 2017.

MELLO, C. A. B. Eficácia das normas constitucionais e direitos sociais. São Paulo: Malheiros, 2010.

MOISÉS, José Álvaro. Democracia e Confiança: por que os cidadãos desconfiam das instituições públicas? São Paulo, SP: USP, 2010.

NOVAIS, Jorge Reis. Direitos sociais: teoria jurídica dos Direitos Sociais enquanto Direitos Fundamentais. Portugal: Editora Coimbra, 2010.

OCDE. Relatórios econômicos e sociais da OCDE Brasil. São Paulo, SP: OCDE, 2015. Disponível em: <http://www.oecd.org/eco/surveys/Brasil-2015-resumo.pdf>. Acesso em: 28 set. 2017.

PEREZ, Carlos Alberto Navarro. Relação entre o ativismo judicial e a atuação deficiente do Poder Legislativo: altruísmo a desserviço da democracia. Revista de Direito Constitucional e Internacional. São Paulo, SP: Editora Revista dos Tribunais, 2012. 


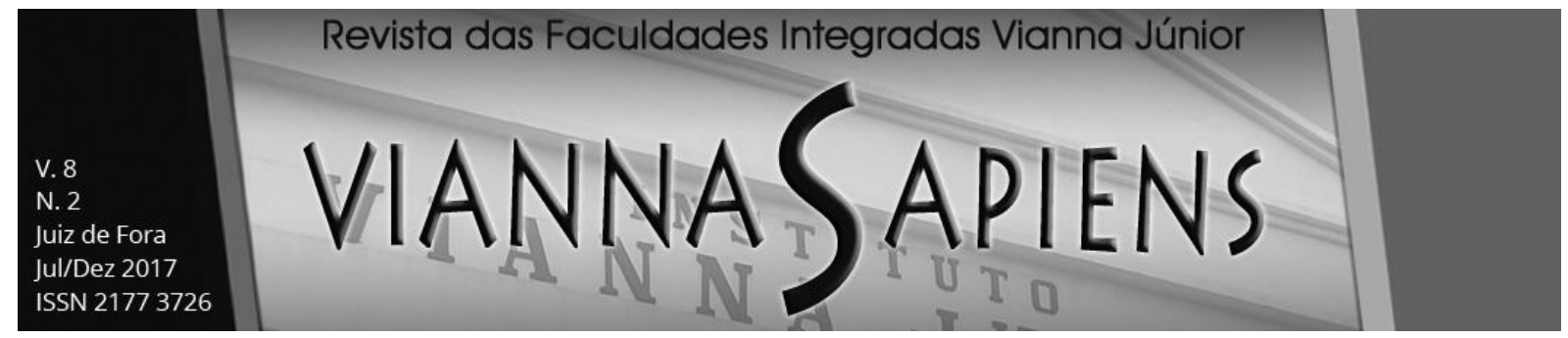

PULIDO, Carlos Bernal. Fundamento, Conceito e Estrutura dos Direitos Sociais. In: SOUZA NETO, Cláudio Pereira de; SARMENTO, Daniel (Coords.). Direitos Sociais. Fundamentos, judicialização e Direitos Sociais em espécie. Rio de Janeiro, RJ: Lúmen Juris, 2008.

ROTHENBURG, Walter Claudius. Inconstitucionalidade por omissão e troca de sujeito: a perda de competência como sanção à inconstitucionalidade por omissão. São Paulo, SP: Editora Revista dos Tribunais, 2005.

SANTANA, Ramiro Nóbrega. A saúde aos cuidados do judiciário: a judicialização das Políticas Públicas de assistência farmacêutica no Distrito Federal a partir da jurisprudência do TJDFT. Dissertação (Mestrado em Direito, Estado e Constituição) da Faculdade de Direito da Universidade de Brasília, UnB, Brasília, 2009.

SARLET, Ingo Wolfgang. A Eficácia dos direitos fundamentais. Porto Alegre, RS: Livraria do Advogado, 2006.

A assim designada proibição de retrocesso social e a construção de um direito constitucional comum latinoamericano. Revista Brasileira de Estudos Constitucionais, RBEC. Belo Horizonte MG: ano 3, n. 11, jul./set. 2009.

SHALDERS, André. Gastos do SUS com decisões judiciais chegam a 1,17 biIhão em 2016. Disponível em: <https://www.poder360.com.br/brasil/gastos-do-suscom-decisoes-judiciais-chegam-a-r-117-bilhao-em-2016/>. Acesso em: 29 set. 2017.

TONNELLI, Maria L. Q. A Judicialização da política e a soberania popular. Dissertação (Mestrado do Departamento de Filosofia da Faculdade de Filosofia, Letras e Ciências Humanas) da Universidade de São Paulo, USP, São Paulo, 2013.

TRAVASSOS, Marcelo Z. Minimalismo, maximalismo e jurisdição constitucional dos Direitos Fundamentais. In: SARMENTO, Daniel (Org). Jurisdição constitucional e política. Rio de Janeiro, RJ: Forense, 2015. 


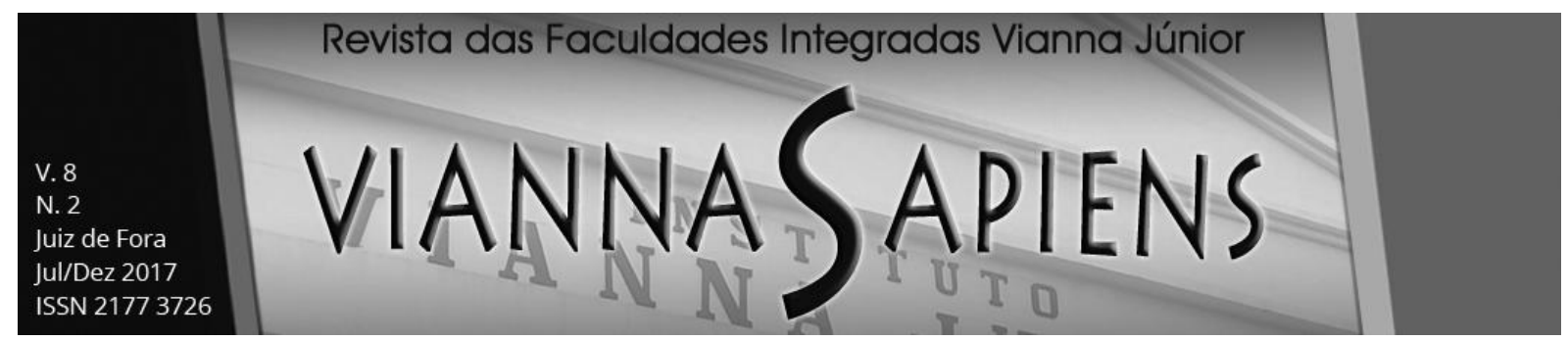

VENTURA, M; SIMAS, L; PEPE, V. L. E; SCHRAMM, F. R. Judicialização da saúde, acesso à justiça e efetividade do direito à saúde. Physis, v. 20, n. 1, Rio de Janeiro, RJ: 2010. Disponível em: <http://www.scielo.br/scielo.php?pid=S010373312010000100006\&script=sci_arttext>. Acesso em: 30 set. 2017.

WANG, Daniel W. L. Courts as healthcare policy-makers: the problem, the responses to the problem and problems in the responses. São Paulo, SP: Fundação Getúlio Vargas, FGV, 2013. Disponível em: <http://papers. ss-

rn.com/sol3/papers.cfm?abstract_id=2335145 > . Acesso em: 28 set. 2017. 